\title{
THE PROBLEM OF EUROPEAN FRESHWATER POPULATIONS OF GAMMARUS DUEBENI LILJEBORG, 1852
}

\author{
by \\ S. PINKSTER, A. L. DENNERT, B. STOCK \& J. H. STOCK (coordinating editor) \\ Institute of Taxonomic Zoology (Zoölogisch Museum) \\ University of Amsterdam, The Netherlands
}

\begin{abstract}
SUMMARY
In addition to the well-known freshwater occurrence of Gammarus duebeni in the inland of Ireland, a similar inland occurrence in the western part of Brittany (= Bretagne, France) is demonstrated. In Brittany, as in Ireland, G.duebeni occurs in waters with low sodium concentrations (often less than $23 \mathrm{mg} / \mathrm{l}$ ), whereas elsewhere in its range, $G$. duebeni lives in waters with a raised sodium content (either in mixohaline waters, or in "fresh" waters loaded with salts through gales from sea). Reid has proposed the designation G. duebeni $\alpha$ for the Irish freshwater form, G.duebeni $\beta$ for the brackish water form. The subdivision of $G$.duebeni is strongly reinforced by the findings of Sutcliffe et al., indicating physiological differences between the $\alpha$ and $\beta$ form. In the present paper, it is shown that significant morphometrical differences exist between the two forms, especially in the length/width ratio of the merus of the fifth leg. A mathematical test, the coefficient of difference, for this character shows it is around or above the standard of subspecific difference. On the other hand, all possible crosses between limnic animals from Eire and Brittany, and mixohaline animals from northern France and Holland, proved to be fertile.

The available evidence (spatial isolation through different habitat, important physiological and morphological differences, interfertility) points very obviously in the direction of two different subspecies: the one, the nominate subspecies, living in waters with rised ion concentrations (restricted neotype locality, supralittoral rockpools at Stora Kalsöy, near Bergen, Norway); the other, celticus Stock \& Pinkster, 1970, living in waters with low ion - in particular sodium - concentrations (type locality Lough Corrib, Eire).

A detailed examination of the distribution pattern of $G$.duebeni celticus, and competing gammarids like $G$. pulex and Echinogammarus berilloni, in the inland of Brittany (Bretagne), makes it probable, that G.duebeni was the oldest freshwater species in that area (presumably originating from mixohaline or marine ancestors in one of the earlier interglacial periods), and that $G$. pulex and $E$. berilloni were later, postgiacial, invaders in that part of Europe.
\end{abstract}

\section{§ I. INTRODUCTION}

I-1. Gammarus duebeni is predominantly a species from brackish coastal waters, with a marked preference for rather marginal biotopes, such as supralittoral rockpools. Besides, G.duebeni is known from a number of freshwater habitats, discussed in detail by Hynes (1954) and Sutcliffe (1967a). The freshwater habitats clearly fall into two groups, as Sutcliffe (1967a) emphasized, viz. (1) isolated near-coast localities, where $G$. duebeni is restricted to only a few streams or rivers, which have under influence of south-westerly gales a rather high concentration of salt from the sea, especially of sodium, and (2) not confined to coastal localities; this is the case in Ireland, where G. duebeni thrives in waters with a low ion content.

I-2. Sutcliffe \& Shaw, 1968, demonstrated that animals from Irish inland populations are physiologically distinct from G. duebeni living in brackish water localities, whereas those living in freshwater, near-coast localities, react physiologically similar to the brackish water animals. The physiological differences pertain to the sodium regulation. Animals from brackish and near-coast localities can live temporarily in waters with a low sodium concentration, but they achieve sodium balance concentrations only for short periods. These animals can osmoregulate without difficulty at external sodium concentrations of 1 to $2 \mathrm{mM} / 1$ $(=23-46 \mathrm{mg} / \mathrm{l})$. However, Irish animals were experimentally kept alive and healthy at an external sodium concentration of $0.25 \mathrm{mM} / 1(=5.75 \mathrm{mg} / \mathrm{l})$. In fact, it is significant that the lowest sodium concentration found in an Irish stream containing G. duebeni is just above this level $(0.27 \mathrm{mM} / 1$, see Sutcliffe, $1967 \mathrm{a} ; 0.34 \mathrm{mM} /$, see table $\mathrm{V}$ in this paper). 
I-3. G. duebeni was also recorded from Bretagne (= Brittany, France), in wells (Den Hartog \& Tulp, 1960: 140) and streams (Hynes, 1959), but Sutcliffe (1967a) supposed that the latter records at least pertain to freshwater habitats with a high concentration of sea salts, since the localities mentioned by Hynes are on a small exposed peninsula, up to $2 \mathrm{~km}$ from the sea. However, in a mimeographed report, Rijnberg et al., 1967, showed that G. duebeni is not restricted to nearshore localities in Bretagne. The present paper will show. that the distribution of G.duebeni in western Bretagne is similar to the situation found in Ireland, and that the French G. duebeni occurs plentifully in waters far inland, and with a low salt concentration (the lowest observed sodium concentration in a Breton stream was $0.35 \mathrm{mM} / \mathrm{l}$, which is in fact a value very similar to the lowest concentration we recorded in Eire, viz. $0.34 \mathrm{mM} / \mathrm{l}$ ).

Furthermore, the presence of morphological differences of subspecific order will be demonstrated between freshwater and brackish populations, and a historical zoogeographic theory is developed to account for the distribution of $G$. duebeni as we find it nowadays.

\section{$\S$ II. GEOGRAPHIC DISTRIBUTION OF GAMMARUS DUEBENI IN EUROPE}

II-1. Gammarus duebeni is chiefly distributed in near-coast localities along the temperate and cool coasts of western and northern Europe. Only in two areas (Ireland and Bretagne) freshwaters far inland are populated. The southernmost distribution limit lies on the south coast of Bretagne, the westernmost limit in Ireland, the northernmost limit in Greenland and Iceland, and the easternmost limit in the White Sea and Tschesskaja Bay (Gurjanova, 1951). Records of this species from the Black Sea (see e.g. Miloslawskaja, 1931), and from the Bassin d'Arcachon (Salvat, 1962) presumably support on confusion with other species.1) For further details concerning the geographic distribution in Europe and North America, the reader is referred to Hynes, 1954: 40.

\footnotetext{
1) As far as Salvat's records from the Bassin d'Arcahcon (France) are concerned, our opinion could recently be confirmed: thanks to the friendly cooperation of Dr. B. Salvat, Ecole pratique des Hautes Etudes, Paris, we could reexamine his material, which proved to exist of a mixture of three species of Gammarus, viz., locusta (L.), insensibilis Stock, and crinicornis Stock, none of the specimens being G.duebeni, however.
}

\section{$\S$ III. THE BIOTOPES INHABITED BY GAMMARUS DUEBENI IN EUROPE}

III-1. Gammarus duebeni is a widespread species in western and northern Europe, inhabiting a variety of biotopes. In a general way, these biotopes can be divided into the following categories: 1) In waters with low sodium concentrations (thus usually far from the sea)

A. In running waters (streams, rivers). In this category fall the Breton and part of the Irish populations. In Bretagne: competition with $G$. pulex.

B. In larger bodies of freshwater (lakes, loughs). Chiefly in Ireland. No competition (or by $G$. lacustris?)

2) In waters with raised sodium concentrations

A. In smaller standing waters, near to the sea. Due to the small size of the waterbody, extreme temperature variations are possible. Through evaporation and rainfall, the salinity shows also drastic variations.

a. With direct influence of spring- or stormtides.

This grouping chiefly comprises the supralittoral rockpools, which form the most charasteristic habitat for the species, at least in the more temperate part of its range, i.e. along the English and French Channel coast up to the southern part of Scandinavia. No competition with other gammarids.

b. Without direct influence of spring- or stormtides. This grouping chiefly comprises smaller brackish inland waters, such as ditches, canals, lagoons, receiving sea salts through seepage through salt-loaded gales, etc. Competition with G. zaddachi.

B. In larger brackish waterbodies. Due to the larger size of the waterbody no extreme temperature and salinity variations occur. With this category classify larger inland seas, like the Baltic and the former Zuydersea. Various competitors may exist locally, in the former Zuydersea e.g. G. tigrinus.

C. In running waters, near to the sea.

a. With rapid, periodic salinity changes (changes roughly every 6 hours): estuaries. G. duebeni is found throughout its range in estuaries; strong competition with $G$. salinus and $G$. zaddachi.

b. With irregular salinity changes: small springs in seacliffs. Such fresh springs or trickles are often found on the slope of seacliffs, emerging directly from the (calcareous) rocks, or 

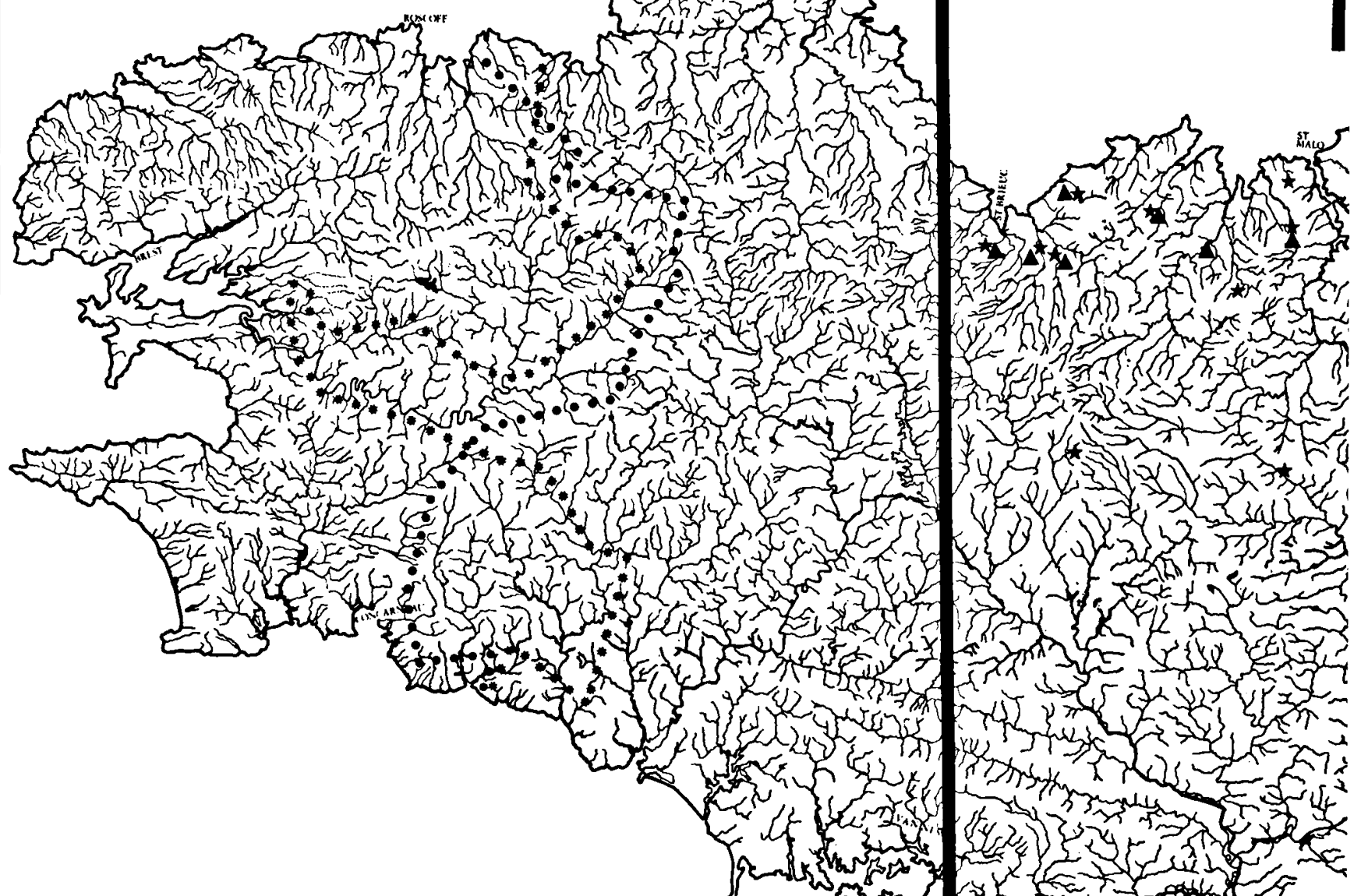

SEE DETAILED MAPS

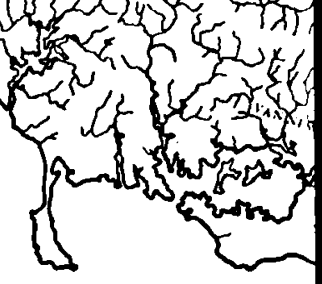

\section{(}

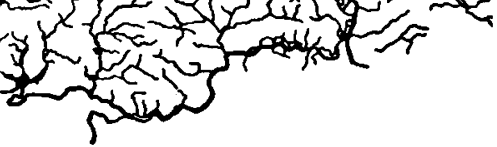




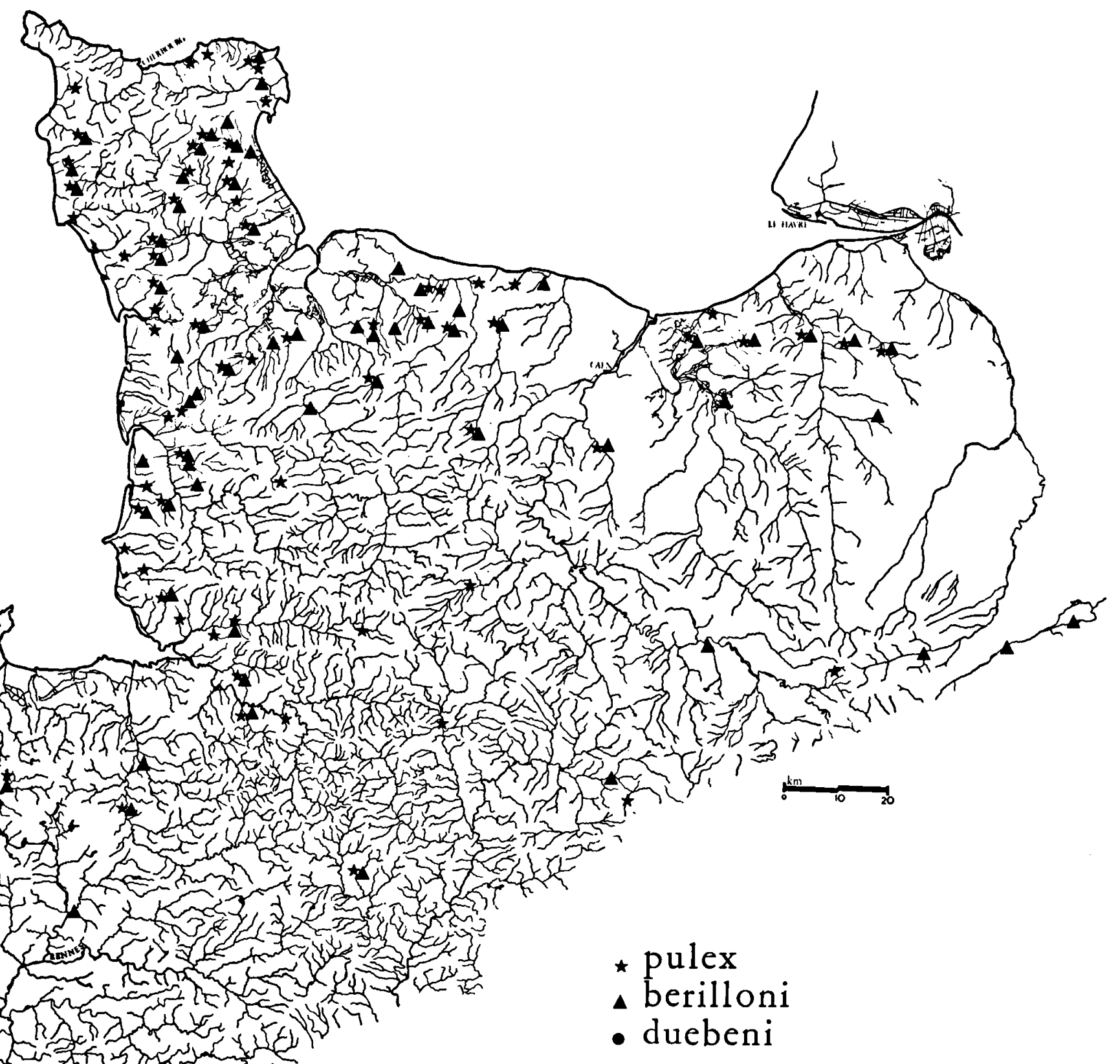

Fig. 1. The distribution of three species of gammarids in inland waters of Bretagne and Normandy. In the westernmost part of Bretagne, the western dispersel boundary of $G$. pulex is indicated by asterisks, the eastern dispersal boundary of $G$. duebeni by dots. Situation as found in September 1969. 
emerging on the level of contact between permeable and non-permeable layers of sediment; loaded, through seawinds, with $\mathrm{Na}$ and $\mathrm{Cl}$ ions; fast salinity changes possible at springtides through spray. No competition.

III-2. It should be noticed that several of these biotopes grade into one another. So, biotope 1 (rivers and streams) merges into biotope $2 \mathrm{C} \mathrm{a}$ (estuaries), and category 2B (larger inland waterbodies) merges into $2 \mathrm{~A} \mathrm{~b}$ (smaller inland waterbodies).

III-3. In addition to the apparent tolerance of G.duebeni as to salinity changes, it is of some importance to notice that $G$. duebeni is also capable of living for some time outside the water. We have observed G. duebeni in Ambleteuse (Pasde-Calais, northern France), living in pools on tidal marshes, slightly below the springtide level; these pools dry out entirely during the neap-tide periods, but the gammarids survive, buried in the mud on the bottom of the pools. Similar experiences have been published by Segerstråle, 1946, 1950; Forsman, 1951; Sutcliffe, 1961; Lagerspetz, 1963.

\section{$\S$ IV. THE DISTRIBUTION OF GAMMARUS DUEBENI IN BRACKISH WATERS IN BRETAGNE}

IV-1. A variety of brackish water biotopes is liable to be inhabited by $G$. duebeni (see $\S$ III-1). However, extensive search of our team has revealed that the biotopes classified under $2 \mathrm{~A}$ and $2 \mathrm{~B}$ in $\S$ III-1, are never populated with the species in Bretagne. On the other hand, the biotopes mentioned under $2 \mathrm{C}$ do contain this species in the investigated area.

As to biotope $2 \mathrm{~B}$ (larger inland seas), this observation is not surprising, since this type of habitat is not available in Bretagne.

It seems more curious that the biotopes mentioned under $2 \mathrm{~A}$ (which comprises supralittoral rockpools and smaller brackish inland waters, such as ditches and lagoons) are uninhabited by $G$. duebeni in Bretagne. At any rate, our observations as to the absence of $G$. duebeni in Breton rockpools (a habitat that is one of the most characteristic for this species farther to the north), are in agreement with those of Hynes (1959 : 154), who also searched in vain in rockpools in southern
Bretagne near Audierne. Hynes' explanation, that G. duebeni lives in Bretagne at the southern limit of its brackish water distribution, and that the severe temperature régime in rockpools excludes it from that habitat, is not disproved by our present observations. On the contrary, we have found, like Hynes, G.duebeni in some places in brackish running waters in Bretagne, thus in the relatively cool mouths of estuaries and in small cool trickles 2 ) on seacliffs (categories $2 \mathrm{C} \mathrm{a}$ and $2 \mathrm{C} \mathrm{b}$ in $\S$ III-1). These brackish localities, wherein $G$. duebeni was found, are marked with large dots in fig. 2.

The absence of $G$. duebeni in Breton brackish lagoons might partially also be due to the presence of Gammarus insensibilis in that type of biotope (see Stock, 1967), which might be a competing species.

\section{$\S \mathrm{V}$. THE DISTRIBUTION OF GAMMARUS $D U E B E N I$ IN FRESH WATERS IN WESTERN FRANCE}

V-1. Hynes, 1959, was the first to report $G$. duebeni from streams in Bretagne (= Brittany, France). Since his records are all from an exposed peninsula, near the Pointe du Raz, and not far (at most $2 \mathrm{~km}$ ) from the sea, Sutcliffe (1967a) considered these animals as the brackish water form of $G$. duebeni living in fresh water, in which the ion content is raised through action of gales from the ocean. However, in a mimeographed report, Rijnberg et al., 1967, demonstrated that G.duebeni is not restricted to nearshore localities in Bretagne.

Following a suggestion made by Hynes (1959: 153) a detailed survey of the distribution of $G$. duebeni was started in September 1969 by a team of staff members and biology students of the University of Amsterdam. During this survey, 642 stations in Normandy and Bretagne were visited, of which 532 stations were positive in yielding gammarids.

\section{V-2. Short description of the stations}

In the following discussion, we have used the name Normandy for the land west of the line Caen-Avranches, the name Bretagne for the land west of the line Avranches-La Baule. Leaving

2) Found in one locality only in this biotype, viz., on the isle of Ouessant near the village Lampaul. 


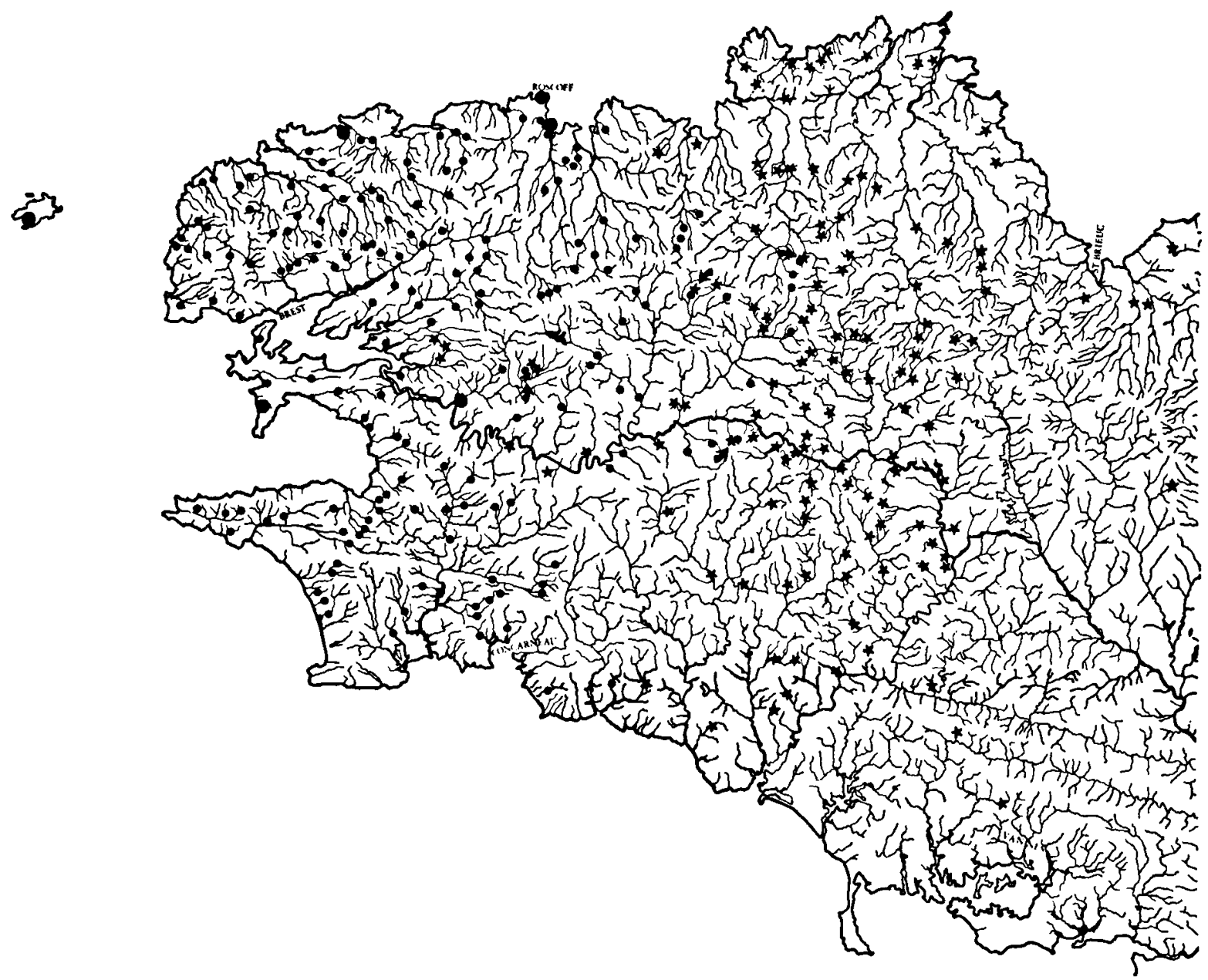

Fig. 2. The distribution of Gammarus pulex (asterisks), Gammarus duebeni duebeni (large dots), and Gammarus duebeni celticus (small dots) in western Bretagne. Arrows

aside the samples that contained brackish water species not interesting us right now (as G. chevreuxi, G. zaddachi, members of the G. locustagroup), there remain 65 samples in Normandy and 364 samples in Bretagne. A water analysis was made at nearly every station for the following factors: temperature, $\mathrm{pH}$, chlorinity, sodium- and calcium-concentration.

The temperature readings were done with mercury thermometers, scale in $0.1^{\circ} \mathrm{C}$. The $\mathrm{pH}$ was, with a few exceptions, measured with the aid of indicator paper. The chlorinity was determined with an E.E.L. electric titrator. Sodium was measured with an E.E.L. flame photometer, and calcium by spectographic titration.

a) Temperature

The surface temperature in the streams sampled indicate the four stations where G. pulex and G.duebeni celticus coexist. Based on the situation in September 1969.

ranged in the observation period (September 1969) between $12.8^{\circ}$ and $18.7^{\circ} \mathrm{C}$. Since these data correspond entirely with what is to be expected in this part of Europe in late summer, no special attention will be given to them.

b) $\mathrm{pH}$ (table I)

As Bretagne is composed largely of metamorph, non-calcareous rocks, it is not surprising that the $\mathrm{pH}$ traject between 4.5 and 5.5 is predominantly represented.

In Normandy, calcareous rocks are present, which is reflected in the $\mathrm{pH}$ traject between 5.0 and 6.5 predominantly represented.

c) Chlorinity (table II)

With the exception of places with estuarine influences, the chlorinity in inland Bretagne and Normandy is low. The majority of the samples 


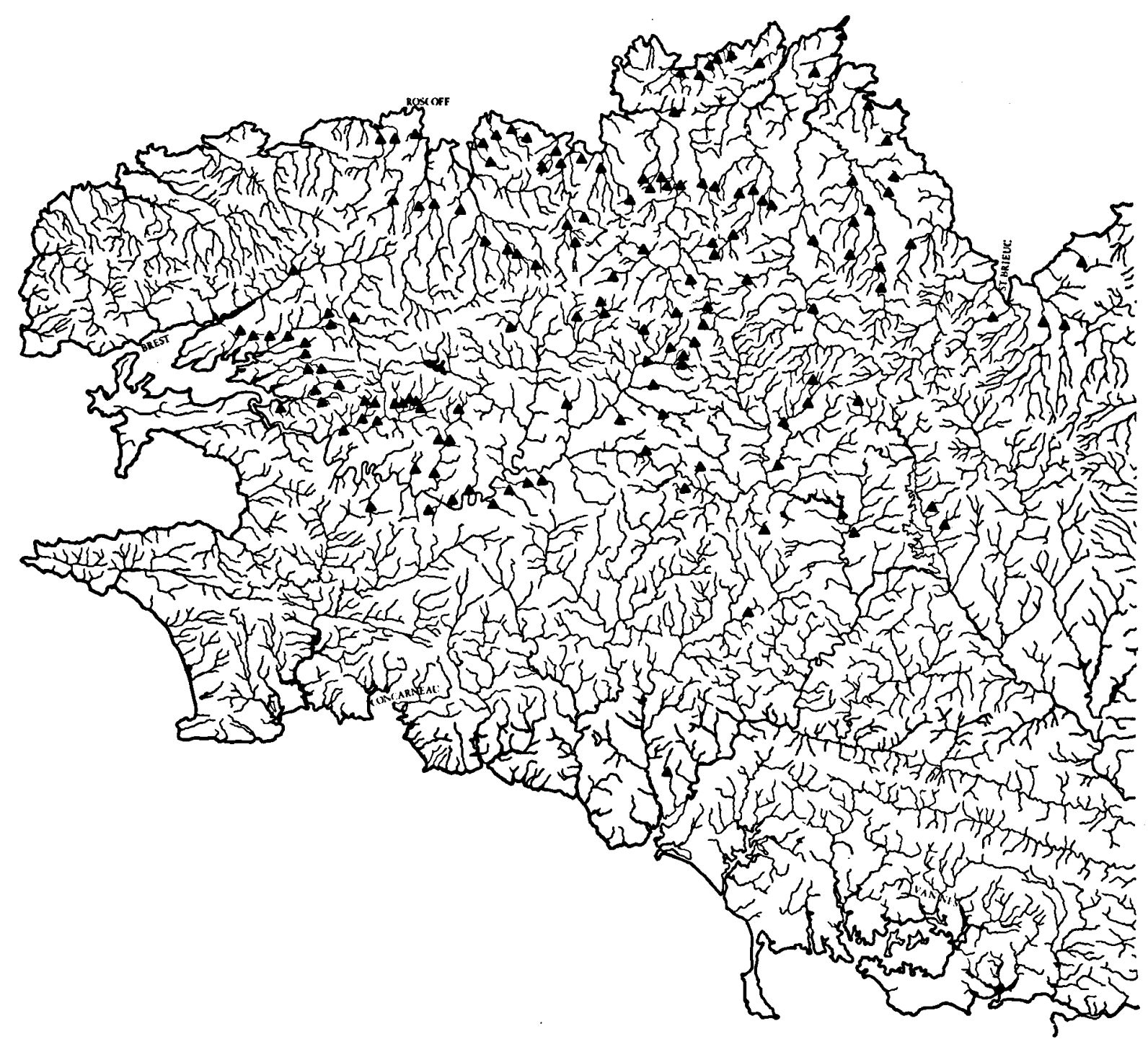

Fig. 3. The distribution of Echinogammarus berilloni in western Bretagne. Based on the situation in September 1969.

was taken at chloride concentrations of less than $50 \mathrm{mg} / \mathrm{l}$ (mean for Bretagne $39.8 \mathrm{mg} / \mathrm{l}$, for Normandy $32.7 \mathrm{mg} / \mathrm{l})$.

d) Sodium-concentration

The map (fig. 4) shows the isohalines enclosing areas with less than 15,25 , and $35 \mathrm{mg} \mathrm{Na} / 1$, respectively. The general picture is that nearshore areas have a higher sodium-content than inland areas. This corresponds well with the idea, that the sodium in natural waters chiefly is carried in by winds from the sea. There are in addition some inland pouches of higher sodium-concentrations, the most marked of which is found in a narrow stretch S. of La Rance, where concentrations up to $75 \mathrm{mg} / \mathrm{l}$ have been found. These pouches corre- spond most probably with geological salt deposits.

The central axis of Bretagne has low sodium contents $(<15 \mathrm{mg} / \mathrm{l})$; in westward direction this axis splits into two "tongues" poor in $\mathrm{Na}$, each tongue corresponding witb a mountain chain: the Montagne d'Arrée is the northernmost chain, the Montagne Noire the southernmost.

\section{e) Calcium-concentration}

The observations for the calcium concentrations run completely parallel to those for the $\mathrm{pH}$. The great majority of the Breton waters are acid and soft, in Normandy the waters are less acid and contain more or much more calcium (see table III). 

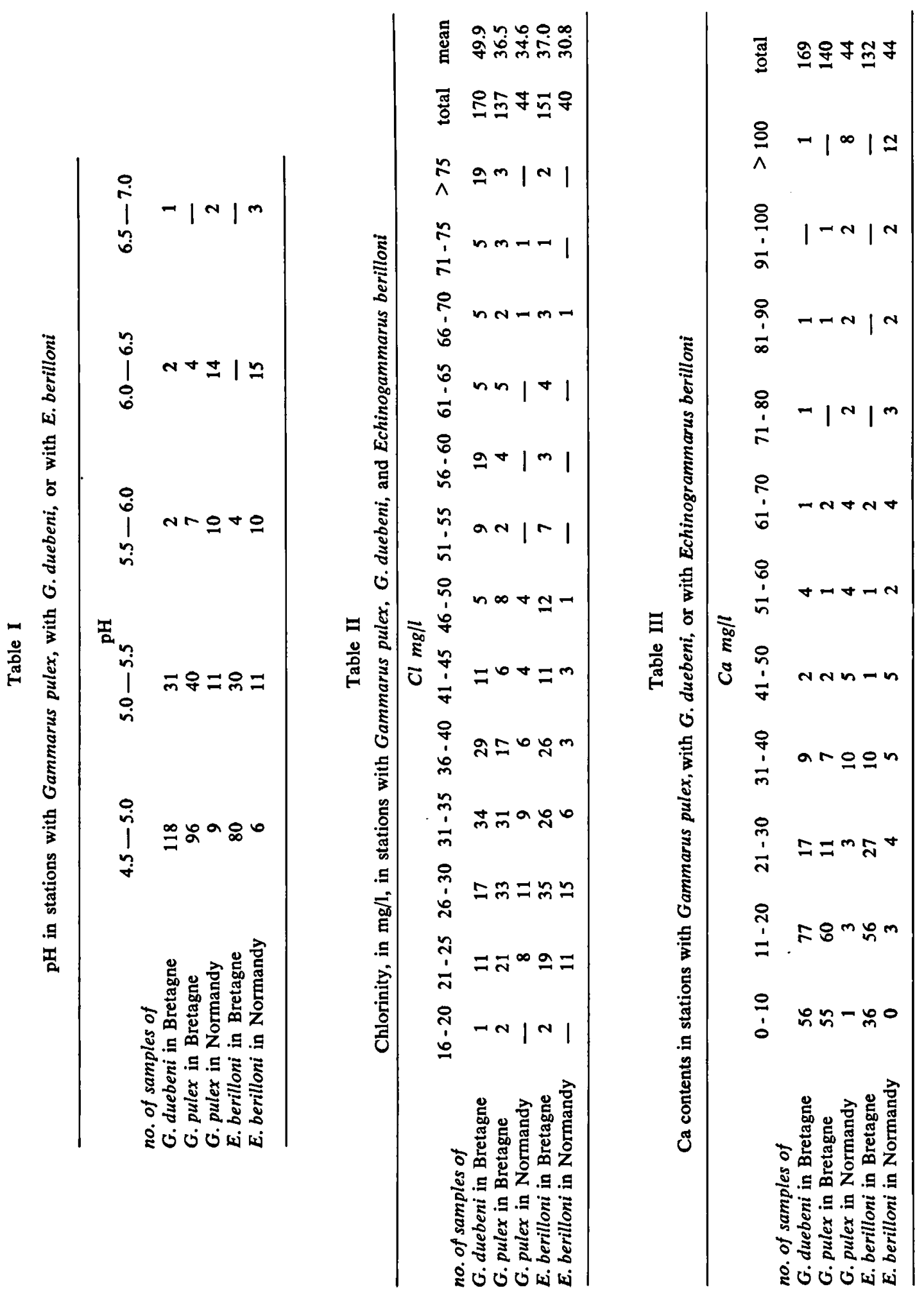


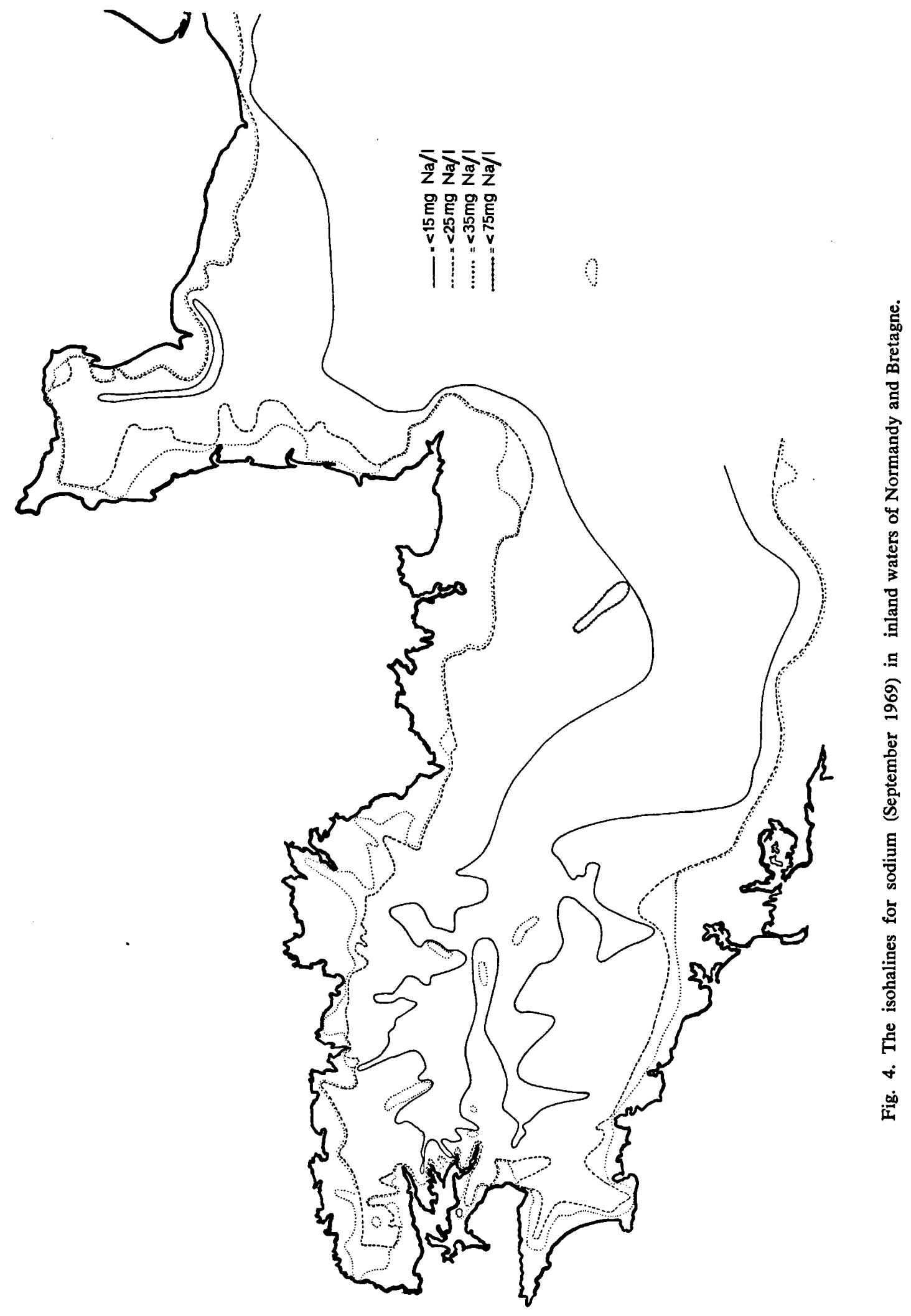




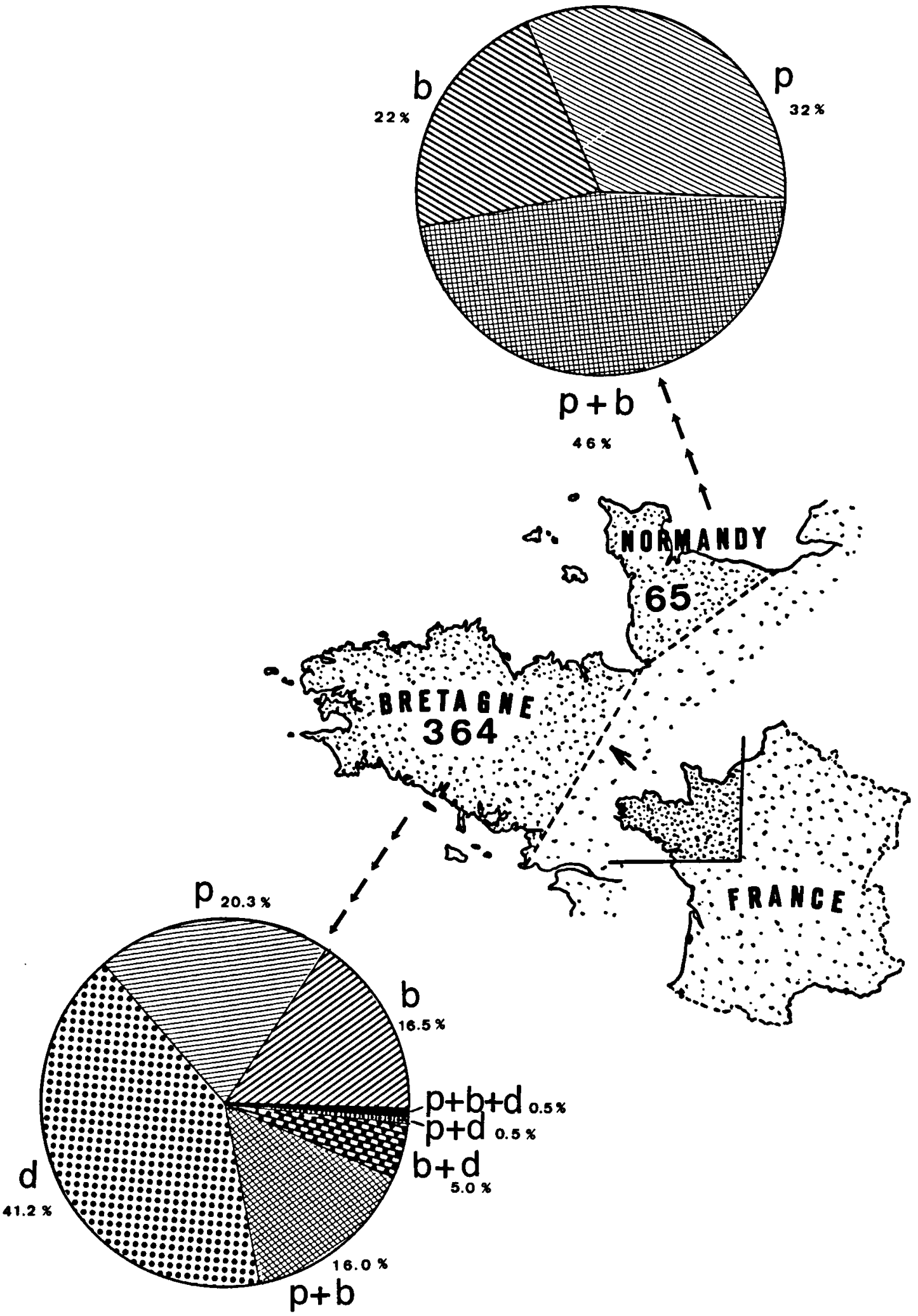

Fig. 5. Composition of 65 postive samples from Normandy and of 364 positive samples from Bretagne ( $\mathrm{p}=$ G. pulex; $\mathrm{b}=$ E. berilloni; $\mathrm{d}=$ G. duebeni). See also table IV. 
Table IV

Composition of positive samples in Normandy $(=\mathrm{W}$. of the line Caen - Avranches) and in Bretagne ( $=$ W. of the line Avranches - La Baule). See also fig. 5.

number of positive samples containing:

G. pulex only
G. duebeni only
E. berilloni only
G. pulex + E. berilloni
G. pulex + G. duebeni
G. duebeni + E. berilloni
G. pulex + G. duebeni + E. berilloni

\begin{tabular}{rr}
$\begin{array}{l}\text { Normandy } \\
65\end{array}$ & \multicolumn{1}{c}{ Bretagne } \\
& 364 \\
$21(32 \%)$ & $64(20.3 \%)$ \\
$0(0 \%)$ & $150(41.2 \%)$ \\
$14(22 \%)$ & $57(16.5 \%)$ \\
$30(46 \%)$ & $54(16.0 \%)$ \\
$0(0 \%)$ & $2(0.5 \%)$ \\
$0(0 \%)$ & $18(5.0 \%)$ \\
$0(0 \%)$ & $2(0.5 \%)$
\end{tabular}

V-3. Species composition of the samples (table IV)

It appears that in Normandy only 2 freshwater species occur, viz. Gammarus pulex and Echinogammarus berilloni (see fig. 1). These two species coexist in nearly half the stations visited (30 stations $=46 \%$, see fig. 5), and thus do not appear to be mutually exclusive.

The composition of the 364 samples in Bretagne (figs. $1,2,3$ ) is more complicated. In 284 stations $(78.0 \%)$ only one species of gammarid was observed: 60 stations $(16.5 \%$ ) had $E$. berilloni only, 74 stations $(20.3 \%)$ had G. pulex only, 150 stations $(41.2 \%)$ had $G$.duebeni only. In the remaining 80 stations $(22.0 \%)$ mixed populations of various species were encountered. Most frequently mixed populations of $G$. pulex and $E$. berilloni were found, viz. in 58 stations $(16.0 \%)$; these two species are, as was apparent also from the sampling in Normandy, not mutually exclusive. More rarely, viz. in 18 stations $(5.0 \%) E$. berilloni was found along with $G$. duebeni. The rarest combinations were G. pulex plus $G$. duebeni ( 2 stations $=0.5 \%$ ) and all three species mixed (also 2 stations). These data clearly reveal that there must be a strong interspecific competition between $G$. duebeni and $G$. pulex, since only in 4 out of 364 stations these two species occurred together, and this cooccurrence is much lower than would be expected on the basis of pure chance only (fig. 5).

\section{V-4. Microgeographic analyses of some streams}

In February and March 1970, a fine sampling grid was laid in three stream systems in the narrow zone of overlapping distribution areas of $G$. pulex and G. duebeni in Bretagne. Mr. H. G. Dennert, Mr. J. Paul, and Miss M. J. van Maren took 146 samples, of which 125 contained gammarids. The position of these three stream systems is indicated in fig. 6 , areas 1,3 , and 4. Moreover, a fourth system ( 2 in fig. 6 ), in which $G$. duebeni coexisted with $E$. berilloni, but in which G. pulex was absent, was also sampled (26 samples, all positive).

This microgeographic analysis revealed the following regularities (see also figs. 7 to 10).

In the westernmost part of Bretagne, where $G$. duebeni is the sole inhabitant of inland waters, it is distributed throughout the stream, thus in the upper courses as well as in the middle and lower reaches.

In the zone of overlap, the picture is quite different. Here $G$. duebeni is restricted to the most upstream reaches of the stream. The species lives almost exclusively in small brooklets, often in just an inch of water in a swampy meadow. As soon as the brook gets wider and deeper, G. duebeni is replaced by $G$. pulex, or lives in coexistence at a certain stretch of the stream with $E$. berilloni. This localization of $G$.duebeni to the narrower streams is plotted in fig. 11, from which it is clear that $63.9 \%$ of the samples of $G$.duebeni were found in streams of less than $1 \mathrm{~m}$ wide, whereas in such narrow streams only $35.0 \%$ of the samples of $G$. pulex and $22.6 \%$ of those of $E$. berilloni were caught. For brooklets of less than $1 / 2 \mathrm{~m}$ wide, the figures are still more illustrative: $30.6 \%$ of the samples of $G$.duebeni, $10.0 \%$ of those of $G$. pulex, and only $3.2 \%$ of those of $E$. berilloni were found there.

Nowhere in the streams of coexistence of $G$. duebeni and $G$. pulex, the former lives downstream of the latter. There are very few instances ( 3 out of 125 positive samples) of joint occurrence of $G$. duebeni and G. pulex at one spot. In all other stations either G. duebeni or G. pulex is found, or - of course - each of these together with $E$. berilloni. Joint occurrence of $G$.duebeni $+E$. berilloni was observed in 11 stations, of G. pulex $+E$. berilloni in 17 stations.

In streams where $G$. pulex is absent, but $G$. duebeni and $E$. berilloni are present (as in the 


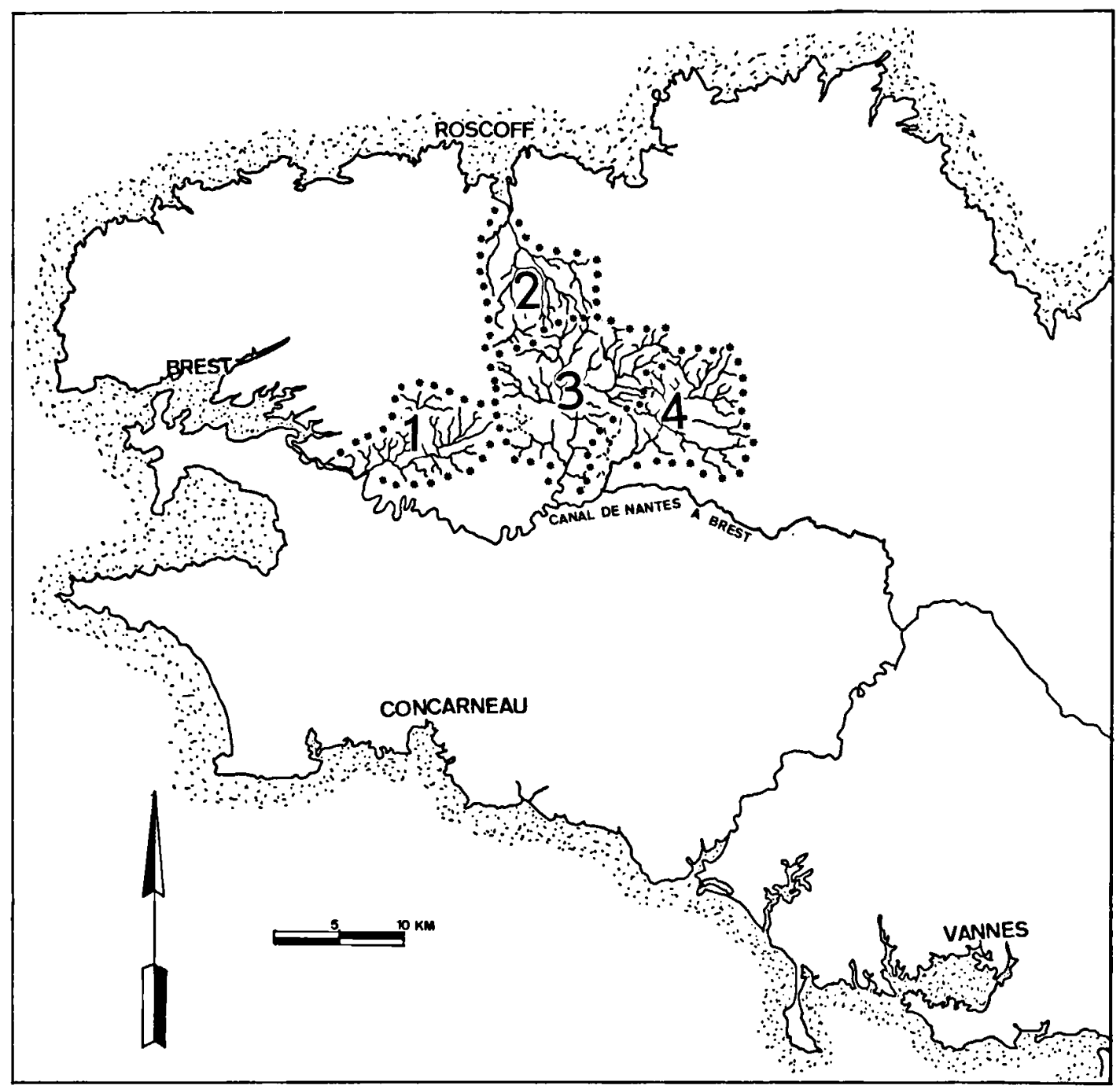

Fig. 6. Map of Bretagne with the location of the areas 1 to 4, where microgeographic analyses were carried out.

rivers around Morlaix, fig. 8), G. duebeni occurs throughout the system, from the source to the estuary, whereas $E$. berilloni tends to be restricted to the middle course of the stream.

This general picture is, as far as $E$. berilloni is concerned, not surprising. This species is known to avoid upper reaches and the spring zone of streams in the rest of its distribution area in northwestern Europe, and it avoids this zone also in Bretagne. In the zone of overlap between $E$. berilloni and $G$.duebeni, there might be a certain competition, but no doubt this competition is less severe than that between G. duebeni and G. pulex, as is proved by the higher instance of joint occurrence of berilloni + duebeni. As soon as $G$. pulex enters into a stream system, G.duebeni is pushed back into the uppermost reaches.

Where estuarine influences become noticeable, E. berilloni has to yield for G. zaddachi.

\section{$\S$ VI. DOES THE CHEMICAL COMPOSITION OF THE WATERS GOVERN THE DISTRIBUTIONS OF GAMMARIDS?}

From the wateranalyses and the distribution of the various species of gammarids in Bretagne and Normandy, various conclusions can be drawn: VI-1. The hardness (Ca concentrations) of the waters has little influence (table III). In Bretagne, most streams contain soft or rather soft waters, in Normandy the $\mathrm{Ca}$ concentrations are higher. In Bretagne $82 \%$ (115 out of 140) of the samples of 


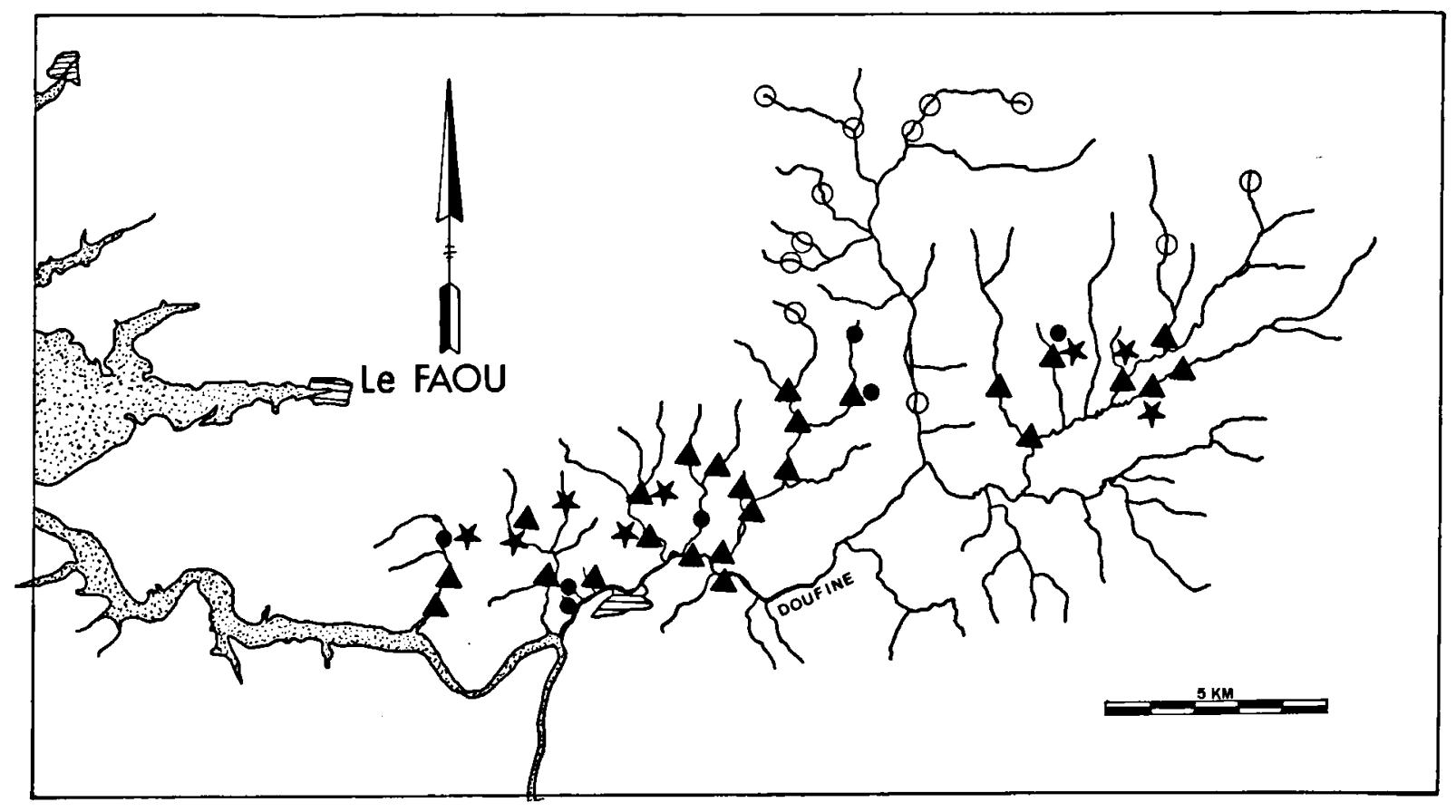

Fig. 7. Microgeographic distribution of Echinogammarus berilloni (triangles). Gammarus pulex (asterisks), and

G. pulex were collected in soft waters $(<20 \mathrm{mg}$ $\mathrm{Ca} / \mathrm{l}$ ), in Normandy $91 \%$ (40 out of 44 ) of the samples of $G$. pulex were collected in hard waters. For E. berilloni the same holds true: in Bretagne $69 \%$ (92 out of 132) of the samples were collected in soft waters, in Normandy $94 \%$ (41 out of 44) in hard waters. G.duebeni, which was found in Bretagne only, shows the same calcium-optimum in its natural waters as G. pulex and E. berilloni, viz. $78 \%$ (133 out of 169 ) of the samples being found at less than $20 \mathrm{mg} \mathrm{Ca} / 1$.

The conclusion that the hardness of the water does not much influence the distribution of certain gammarids, is in complete agreement with Sutcliffe's findings (1967c: 588) for G. duebeni.

VI-2. The picture for the $\mathrm{pH}$ is fully comparable with that for the $\mathrm{Ca}$ concentrations (table I).

VI-3. The sodium distribution in inland waters in Bretagne and Normandy is discussed in $\S \mathrm{V}-2-\mathrm{d}$ and illustrated in fig. 4. When this figure, showing the isohalines for $15,25,35$, and $75 \mathrm{mg} \mathrm{Na} / 1$, is carefully compared with figs. 1,2 , and 3 , in which the distribution of G.duebeni, G. pulex, and $E$. berilloni is plotted, no consistent pattern can be found. G. duebeni is not at all restricted to waters
G. duebeni (dots) in the stream system of the Doufine (= system 1 in fig. 6). Situation as found in February 1970.

with a high sodium concentration (these are, biologically speaking, those with more than $23 \mathrm{mg}$ $\mathrm{Na} / \mathrm{l})$. In fact in 90 out of 166 Breton samples, G. duebeni occurred at sodium concentrations of less than $23 \mathrm{mg} / \mathrm{l}$. On the other hand, the "true" freshwater species (G. pulex and E. berilloni) can penetrate in waters with raised sodium concentrations. So, in Normandy 30 out of 44 streams with G. pulex had more than $23 \mathrm{mg} \mathrm{Na} / \mathrm{l}$.

These results are not in contradiction with data recorded in literature. Sutcliffe $(1967 \mathrm{c})$ showed that G.duebeni from Irish inland waters can survive and reproduce at very low sodium concentrations. Irish natural waters (Sutcliffe, 1967c, and table $\mathrm{V}$ in this paper) have such a low sodium content, just as Breton natural waters.

Data recorded elsewhere in this paper (§ XIII.3) demonstrate that $E$. berilloni and G. pulex can withstand quite considerable concentrations of the external medium, with little ill effect.

At any rate, it seems clear that $G$. duebeni from Bretagne behaves physiologically as the Irish freshwater form (Reid's Gammarus duebeni a), and not as the British freshwater form, which has according to Sutcliffe, 1967 a, a sodium regulation similar to the brackish water form (Gammarus duebeni $\beta$ of Reid, 1939). G. duebeni was found 
Table V

Sodium concentration in $\mathrm{mg} / \mathrm{l}$ of certain fresh waters in western Eire, in the period November $17-19,1969$

Locality

1. Brook between Clonleg Lough and Clonbrick Lough (Co. Clare)

2. Doon Lough, W. of Broadford (Co. Clare)

3. Lough Corrib, about 3 miles N. of Galway (Co. Galway)

4. Spring along highroad T 4, just W. of Oranmore (Co. Galway)

5. Lough Rea near Loughrea (Co. Galway)

6. Brook near Hollymont, N.E. of Gort (Co. Galway)

7. Rockpool at Black Head (Co. Clare)

8. Coker River, S. of Black Head (Co. Clare)

9. Brook S. of Ennistimon (Co. Clare)

10. Spring along road $\mathrm{T} 69$, near Rinneen, $\mathbf{N}$. of Milltown - Malway (Co. Clare)

\begin{tabular}{|c|c|c|c|}
\hline species present & $p H$ & Na mg/l & temp. in ${ }^{\circ} \mathrm{C}$. \\
\hline G. lacustris & 一 & 19.2 & - \\
\hline G. duebeni & - & 12.0 & - \\
\hline G. duebeni & 5.5 & $\left.15.4^{*}\right)$ & 7.00 \\
\hline G. duebeni & 5.5 & 29.4 & 10.50 \\
\hline G. duebeni & $4.5-5$ & 22.1 & 7.95 \\
\hline G.duebeni & $4.5-5$ & 34.0 & 9.55 \\
\hline G. duebeni & - & 17.4 & 10.95 \\
\hline G. duebeni & 5.0 & 7.8 & 11.00 \\
\hline G.duebeni & 4.5 & 29.0 & 9.60 \\
\hline G. duebeni & 5.0 & 26.7 & 10.85 \\
\hline
\end{tabular}

*) Concentration of other important ions (in $\mathrm{mg} / \mathrm{l}$ ): $\mathrm{Cl} 23.0, \mathrm{Ca} \mathrm{79.0,} \mathrm{Mg} 5.4$.

in Bretagne at 166 stations, where the $\mathrm{Na}$ concentrations varied between 8 and $95 \mathrm{mg} / 1$ (mean 27.9); as mentioned earlier, more than half these samples (including several samples containing reproducing specimens) were collected in waters having less sodium than the critical $23 \mathrm{mg} / \mathrm{l}$ limit.

It is also clear that of the three species of gammarids studied in this paper, G. duebeni penetrates more frequently in waters with high salt concentrations. (See fig. 12, which shows that samples with $G$. pulex always contained less than $65 \mathrm{mg} \mathrm{Na} / \mathrm{l}$, whereas $G$. duebeni has been found at concentrations as high as $95 \mathrm{mg} / \mathrm{l}$.)

Finally, the curves for the $\mathrm{Na}$ concentrations in the biotopes of $G$. duebeni in Bretagne and of $G$. pulex in Normandy (see fig. 13) are very similar both in the place of the maximum and in the mean. The distribution of G. pulex and G. duebeni in western France thus does not seem much influenced by the sodium concentrations, at least not in inland waters.

VI-4. In the inland of Bretagne and Normandy, there is little $\mathrm{Na}$ and little $\mathrm{Cl}$. The little salt there is may very well originate from the sea. For 100 analyses of water from streams in Bretagne, the mean ratio sodium/chloride in $\mathrm{mg} / \mathrm{l}$ is 0.58 , which is very close to the ratio of $0.51-0.56$ found in normal sea water (fig. 19). It is not surprising, therefore, that the picture for chloride (table II) is very similar to that of sodium. Here again, $G$. duebeni penetrates more frequently into water with higher chlorinities (19 out of 170 stations, or $11.2 \%$, at $>75 \mathrm{mg} \mathrm{Cl} / 1$ for duebeni; 3 out of 137 stations, or $2.2 \%$ for pulex; and 2 out of 151 stations, or $1.3 \%$ for berilloni).

\section{$\S$ VII. DIFFERENCES IN MORPHOLOGY BETWEEN GAMMARUS DUEBENI FROM BRACKISH AND FROM FRESH WATERS}

VII-1. Reid, 1938, 1939, who was the first to report upon the occurrence of G. duebeni in fresh waters of Ireland, also tried to discriminate on morphological grounds between specimens from brackish waters and from Irish fresh waters, but he states to "have completely failed to find any morphological difference" (1939:211). These negative results have been cited by other authors, but as far as we could ascertain, nobody has tackled the problem again ever since Reid's 


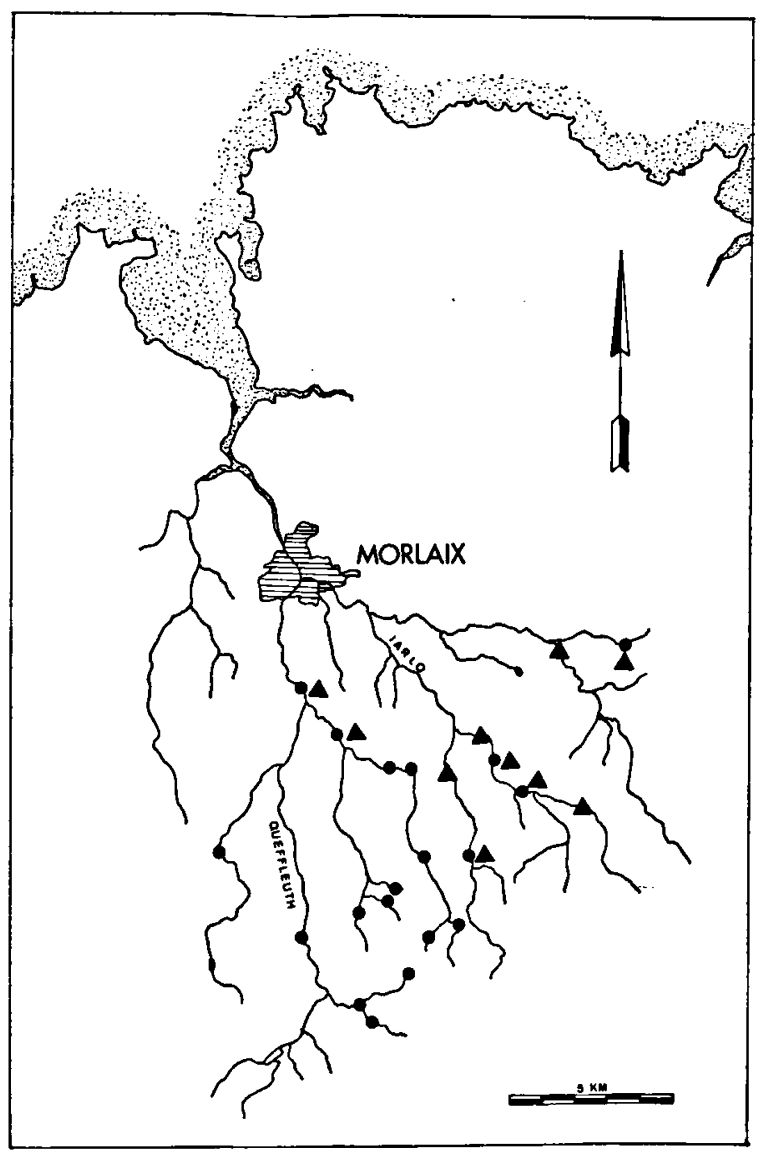

Fig. 8. Microgeographic distribution of Echinogammarus berilloni (triangles), and Gammarus duebeni (dots) in the stream systems of the Jarlo and the Queffleuth $(=$ system 2 in fig. 6). Situation as found in February 1970.

negative efforts. Since Reid states in the same paper that it is very difficult to find clearly distinguishing characters between species so clearly identifyable as G.duebeni and G. pulex, one gets a little suspicious as to the degree of refinement of Reid's efforts, so we reconsidered the problem in detail.

VII-2. Over 600 samples of G. duebeni from coastal habitats in its entire range in Europe (from Iceland and northern Norway in the north, to Ile Ouessant in the south) were examined for this purpose, along with examination of 16 freshwater samples from Eire and near to 400 freshwater samples from Bretagne.

It emerged that certain morphological details looked promising for mathematical or statistical treatment. These characters were: (1) The length/ width ratio of the merus of leg 5 (fig. 14). (2) The length of the peduncle of $A 1$ in relation to the total body length. For practical purposes this relation is expressed in this paper as the ratio 3rd segment of peduncle of $A$ 1/length of cephalon. (It was shown by Dennert et al., 1969: 17, that the cephalon length is directly proportional to the body length in Gammarus.) (3) The ratio length exopod/length endopod in the third uropod (fig. 17).

Figs. 15, 16, and 18 show the results of these morphometric analyses in different populations. The measurements used were taken with the aid of an eye-piece micrometer. Only full-grown males were used, having a cephalic length from $1944 \mu$ (the maximum observed) to $1008 \mu$ (the minimum used).

VII-3. The length/width ratio of the merus of $\mathbf{P} 5$ (figs. 14, 15)

In both the Irish and the Breton freshwater populations, the merus is always twice or more than twice as long as wide. The same character was analysed in 5 brackish water populations, viz. from the Ambleteuse area (dépt. Pas-de-Calais, northern France, chlorinity $1.10 \%_{00}$ at the moment of collecting), from waters around Amsterdam (prov. of North-Holland, The Netherlands, yearly chlorinity $0.3-0.6 \%$ ), from rockpools near Helsinki (Finland, yearly salinity $1-20 \%$ ), from

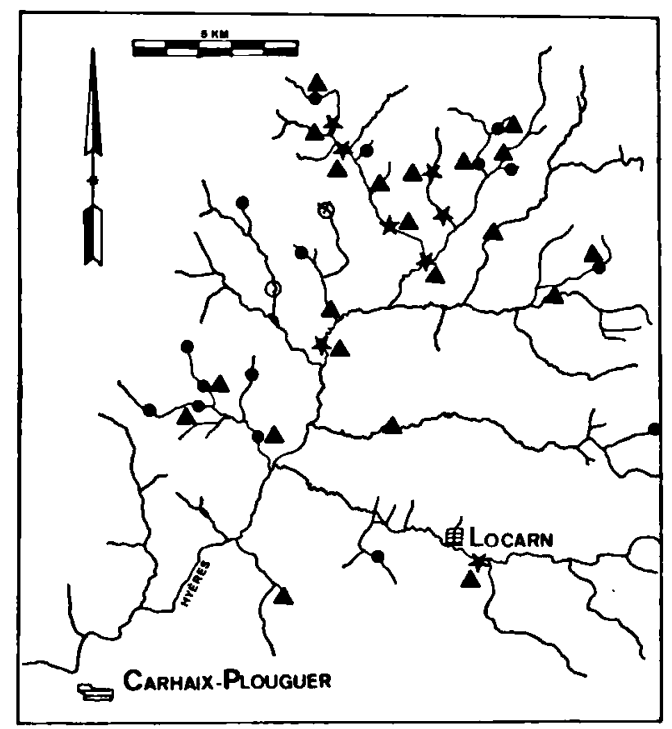

Fig. 9. Microgeographic distribution of Echinogammarus berilloni (triangles), Gammarus pulex (asterisks), and $G$. duebeni (dots) in the stream system of the Hyères $(=$ system 4 in fig. 6). Situation as found in March 1970. 
Bohuslån (Baltic Sea, Sweden, salinity $>6 \%$ ), and from rockpools in Eire (chlorinity 0.016$0.040 \%$ a at the moment of collecting). Since the populations from Holland and northern France were statistically found to show no significant differences (tested with t-test, regression-coefficients, Fo-, and FY-tests), their values have been added up in the histogram. It appears that the great majority of the brackish water animals have the ratio length/width in the $P 5$ merus $\leqslant 2$ (against $\geqslant 2$ in the freshwater animals). Each brackish population was tested against each freshwater population, and the differences were found to be significant to highly significant at the $95 \%$ level. There is no overlap in the standard deviations of the brackish populations on the one side and the freshwater populations on the other.

If one calculates the coefficient of difference (C.D.) according to Mayr, Linsley \& Usinger, $1953: 146$ for the various populations, it appears that the freshwater populations do not differ mutually (C.D. 0.36), that also the brackish populations do not differ mutually (C.D. $0.42-$ 0.92 ), but that differences around or above the standard of subspecific difference 3 ) are found between the various brackish populations on the one side and the two freshwater populations on the other. So Holland + France versus Bretagne gives a C.D. value of 1.25, Holland + France versus Eire of 1.63, Helsinki versus Bretagne of 1.18, Helsinki versus Eire of 1.66 , Bohuslån versus Bretagne of 1.32, Bohuslån versus Eire of 1.62 .

Although there is a slight overlap in the curves for brackish water specimens and those for Irish and Breton freshwater specimens, the length/width ratio of the merus provides a rapid identification tool.

VII-4. The relative length of the first antenna

For the composition of the histogram (fig. 16) the ratio between the length of the 3 rd peduncle segment and the length of the head was taken. As explained above, the length of the head is directly proportional to the total body length. The curves thus obtained show a very wide overlap, but nevertheless it is clear that the curves for the two freshwater populations, Eire and Bretagne, are shifted to the lower values. The values for Eire in

3) This standard is: $75 \%$ of population $A$ is different from $97 \%$ of population B, corresponding with a C.D. value of $\geqslant 1.28$. particular are very significantly lower than those for the other populations $\left(P_{R}<0.0005\right)$. In the C.D.-test, the differences mutually between the brackish populations range from C.D. $0.31-0.48$, mutually between the freshwater populations C.D. is 0.68 , and between the freshwater populations at the one hand and the brackish populations on the other between 0.47 and 1.09. All these values fall well below the subspecific significance level of 1.28 .

VII-5. The relative length of the endopod of the 3rd uropod

The relative length of the endopod is expressed in the histogram (fig. 18) as the ratio between the lengths of uropodal exo- and endopod. For freshwater in Eire and brackish water in Holland the curves do hardly differ (the $t$-test gives a $t$-value of 0.91 at $\mathrm{n}=118$, thus not significant). In freshwater populations from Bretagne, there is a marked tendency for abbreviation of the endopod, resulting in a higher value for the exopod/endopod ratio. The higher value is very significant $\left(P_{R}<\right.$ 0.0005 ), but in the light of the great overlap not of much use for practical identification work. As the histograms suggest already, the C.D. values between the populations are low (Bretagne versus

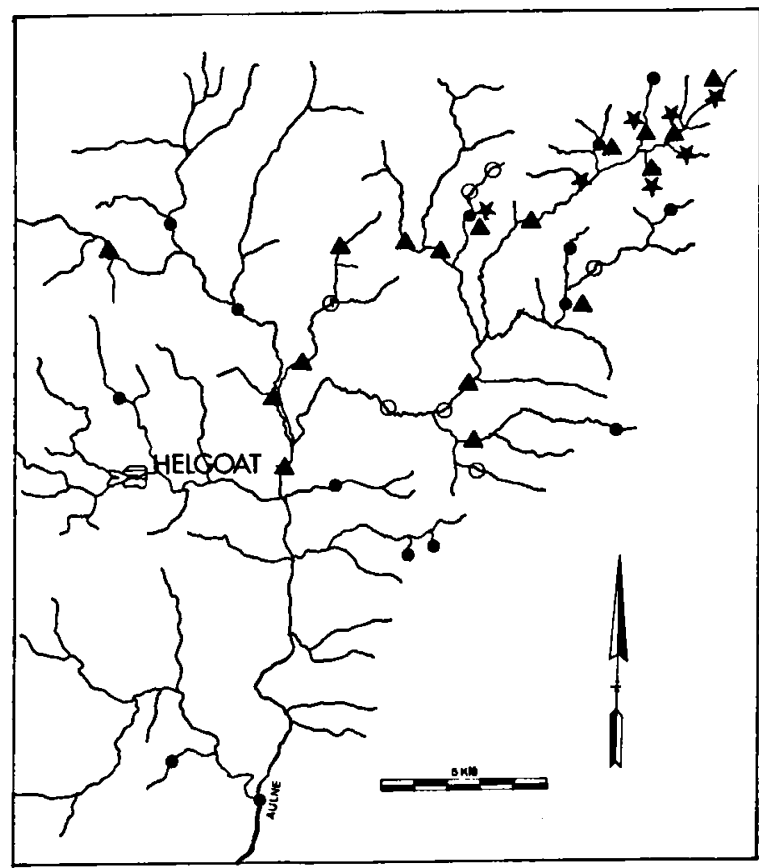

Fig. 10. The microgeographic distribution of Echinogammarus berilloni (triangles), Gammarus pulex (asterisks), and $G$. duebeni (dots) in the stream system of the Aulne (= system 3 in fig. 6). Situation as found in FebruaryMarch 1970. 
Eire 0.44; Bretagne versus brackish 0.65; Eire versus brackish 0.28 ), meaning that the differences observed are not on subspecific level.

VII-6. Summarizing, it can be said that the brackish water populations differ at a subspecific level from the freshwater populations in the length/ width ratio of the merus. The Breton freshwater population is slightly different from the other populations in the shorter uropodal endopod, but - though statistically significant - this character is not of subspecific value. The Irish freshwater populations differ also in a statistically significant way from the others, viz., in the longer relative length of the 3 rd peduncle segment of $A 1$; however, here again the observed difference does not attain subspecific level.

\section{$\S$ VIII. COMPARISON WITH NORWEGIAN MATERIAL}

\section{VIII-1. The original description}

Gammarus duebeni has been described by Liljeborg in 1852. Although there is some persistent superstition in the literature that the type-locality is a warm thermo-mineral spring, salinity $1 \% / 00$, temperature $40^{\circ} \mathrm{C}$, in Greenland (see e.g. Pacaud, 1952 : 98), none of these details is borne out by the original description. On the contrary, it is stated explicitly that G.duebeni was collected by Mr. M. W. von Düben in 1843-44 " $\mathrm{i}$ trakten af Bergen och Christianssund i Norge" (in the surroundings of Bergen and Christianssund in Norway). No reference to any particular environmental condition was given, but since $G$. duebeni is listed together with 105 other arthropods, all of which are marine or polyhaline forms, it can safely be assumed, that the types came from a near-coast locality.

Attempts to locate the types (in Stockholm, Lund, Göteborg, Copenhagen, and Uppsala) failed.

\section{VIII-2. Neotype}

In order to assure stability in nomenclature, especially in the light of the morphological pluriformity observed within $G$.duebeni, it was thought wise to select a neotype for this species and to restrict the type-locality.

No particular trouble was encountered, since all the Scandinavian material examined by us (scme 40 samples) proved to be mutually uniform, and to resemble morphologically the "brackish water form" from the Netherlands and from northern
France. (See figs. 15 and 16 for graphic representation of the morphology of some Scandinavian samples).

We have selected a male, collected in rockpools near Bergen (Norway), as the species neotype (see $\S \mathrm{XI}-2$ ).

VIII-3. Freshwater records of G.duebeni in Scandinavia

There are a few literature records (J. $\varnothing$ kland, 1959; K. A. Økland, 1965; Ofstad \& Solem, 1966) of freshwater occurrence of G. duebeni in Norway. However, all these records are from near-coast localities (J. Økland: slightly brackish

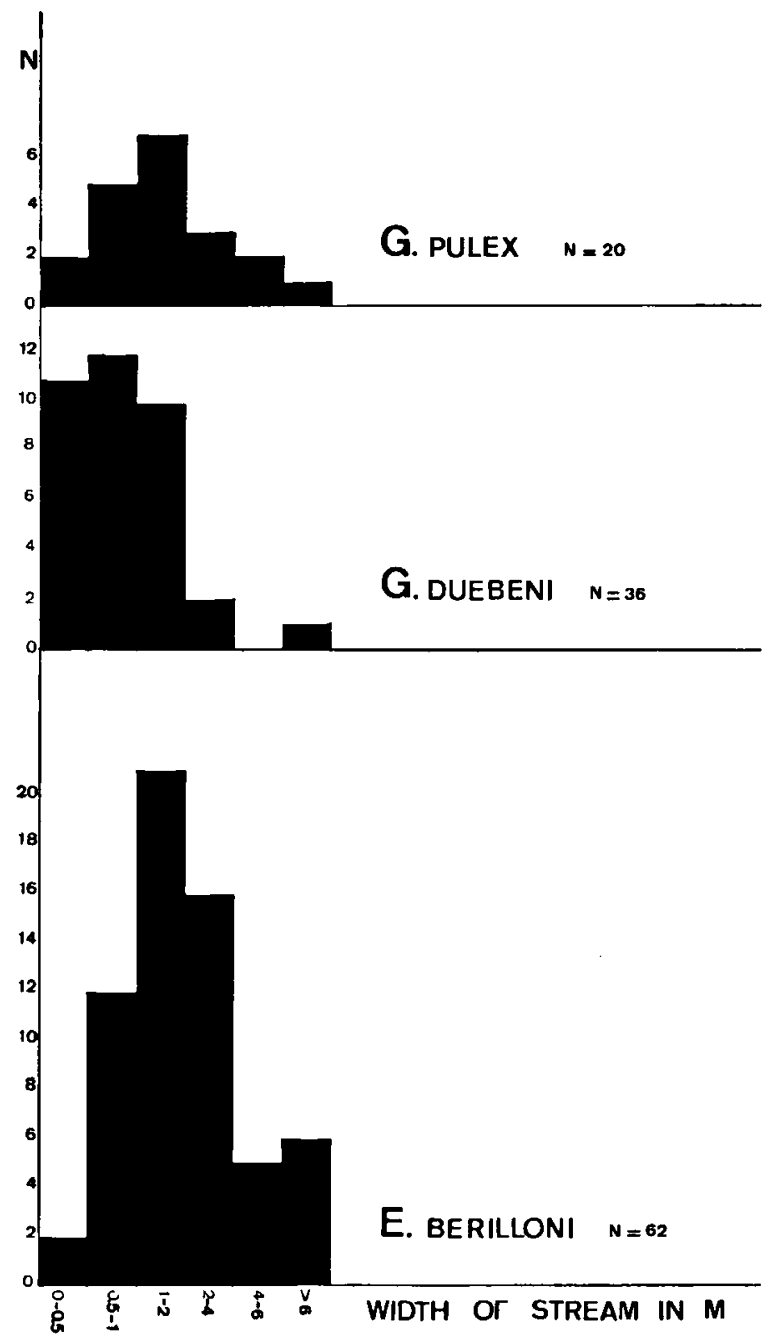

Fig. 11. Distribution of three species of freshwater gammarids in relation to the width of the stream. These data have been recorded in areas of sympatric occurrence of the three species (i.e., stream systems 1,3 , and 4 in fig. 6). G. duebeni is more frequent in the smaller streams, $G$. pulex and $E$. berilloni in the wider streams. 


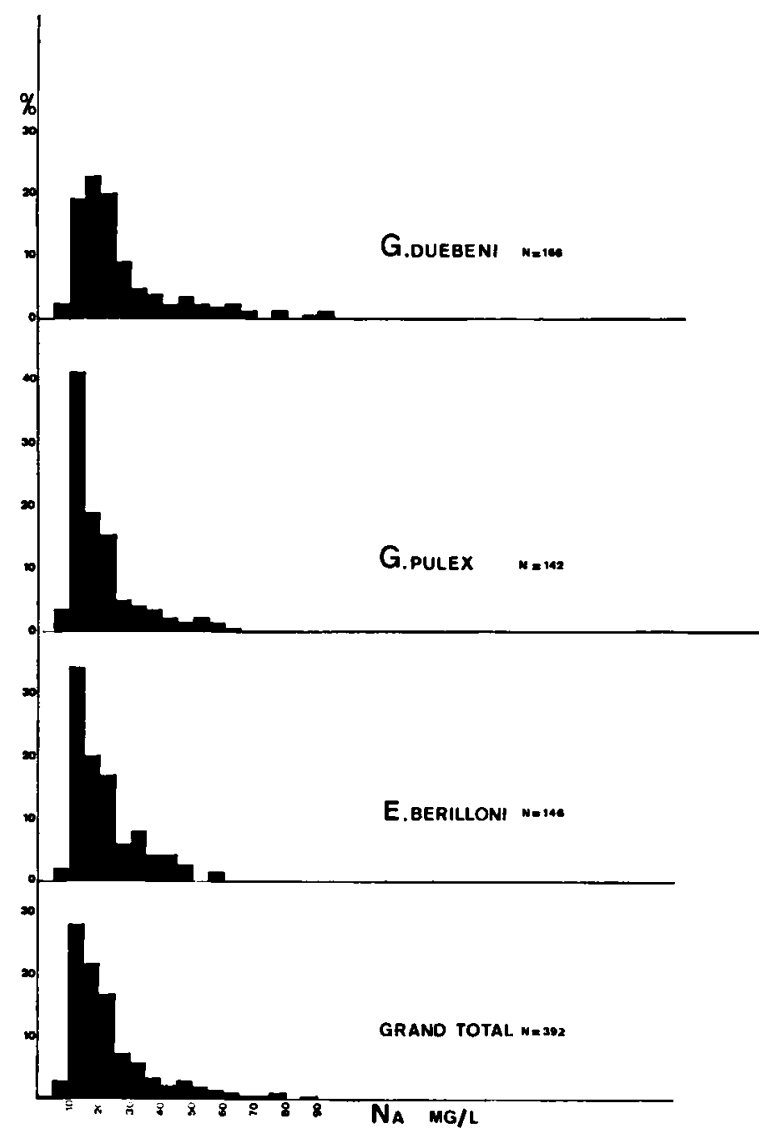

Fig. 12. Sodium contents (in $\mathrm{mg} / \mathrm{l}$ ) in 166 stations of Gammarus duebeni, 142 stations of G.pulex, and 146 stations of Echinogammarus berilloni in Bretagne. Notice that the peaks for G. pulex and E. berilloni correspond with the peak in the lowest histogram, representing the composition of all 392 waters analysed, whereas G.duebeni is found in waters with a slightly higher sodium content.

water, chlorinity $150-1120 \mathrm{mg} / \mathrm{l} ; \mathrm{K}$. A. $\emptyset$ kland: 200-300 meters from the sea; Ofstad \& Solem: 2 to $4 \mathrm{~km}$ from the sea). This makes it, even in the two last-mentioned records which obviously refer to limnic waters with a true freshwater fauna, likely that in the stormy season important amounts of sodium will be deposited in the area. We assume, therefore, in accordance with Sutcliffe's opinion (1967) that the brackish water form cf G. duebeni is involved here.

We have examined one Scandinavian freshwater sample (Zool. Mus. Stockholm, Amph. 3102, from Bohuslån, Väderöarna), and this was morphologically similar to the brackish water form.

\section{§ IX. MORTALITY RATE OF G. DUEBENI FROM FRESH WATER WHEN TRANSFER- RED TO HIGHER SALINITIES}

IX-1. Several experiments are reported upon (e.g., Reid, 1939; Beadle \& Cragg, 1940; Hynes, 1954) in which G.duebeni from brackish water was transferred to lower salinities. All these authors report that the brackish form of duebeni can survive in fresh water, but that it is unable to

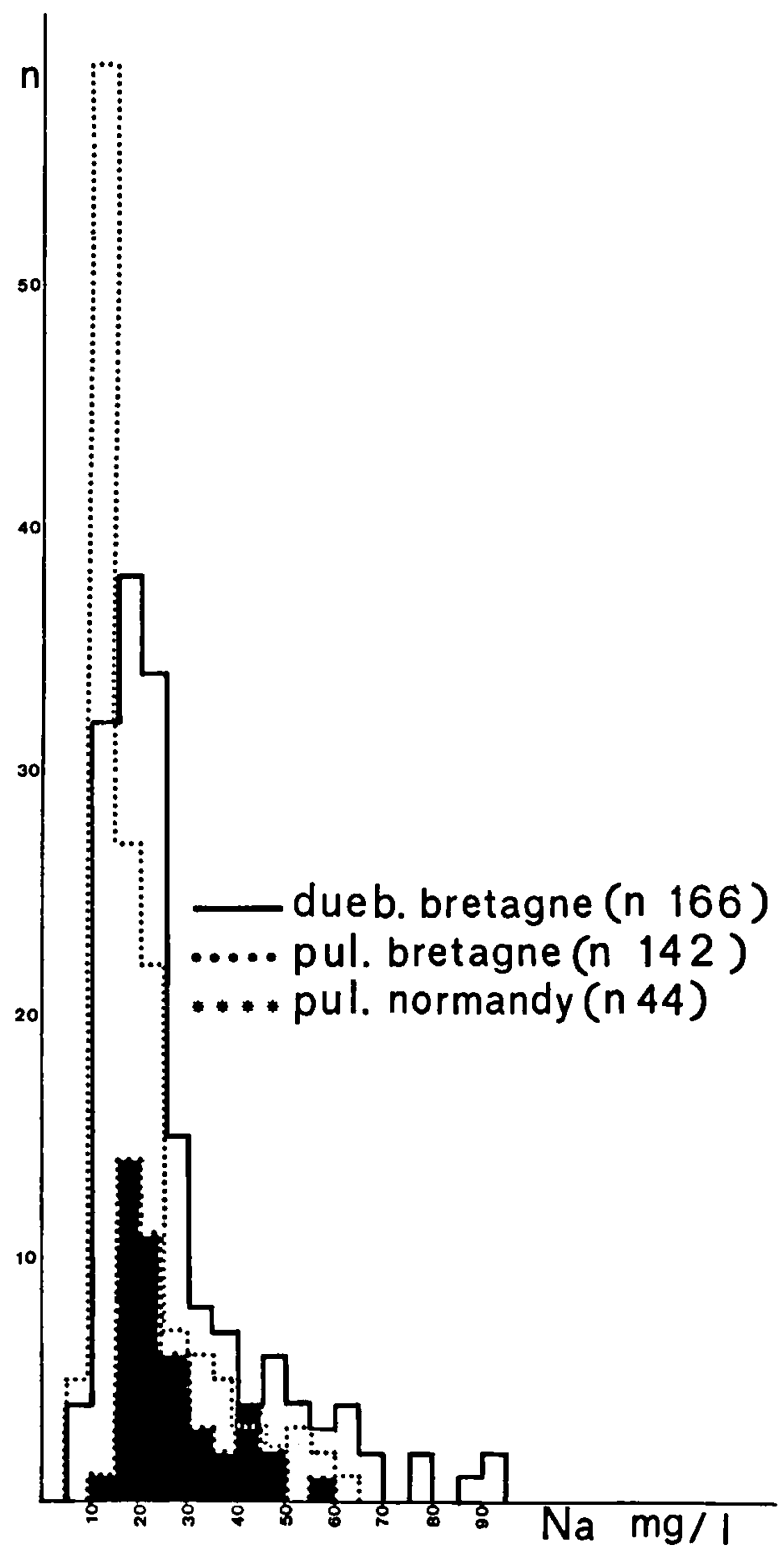

Fig. 13. Sodium contents of 166 stations of Gammarus duebeni and of 142 stations of $G$. pulex, both in Bretagne, as well as of 44 stations of G. pulex in Normandy (blackened part of the graph). 


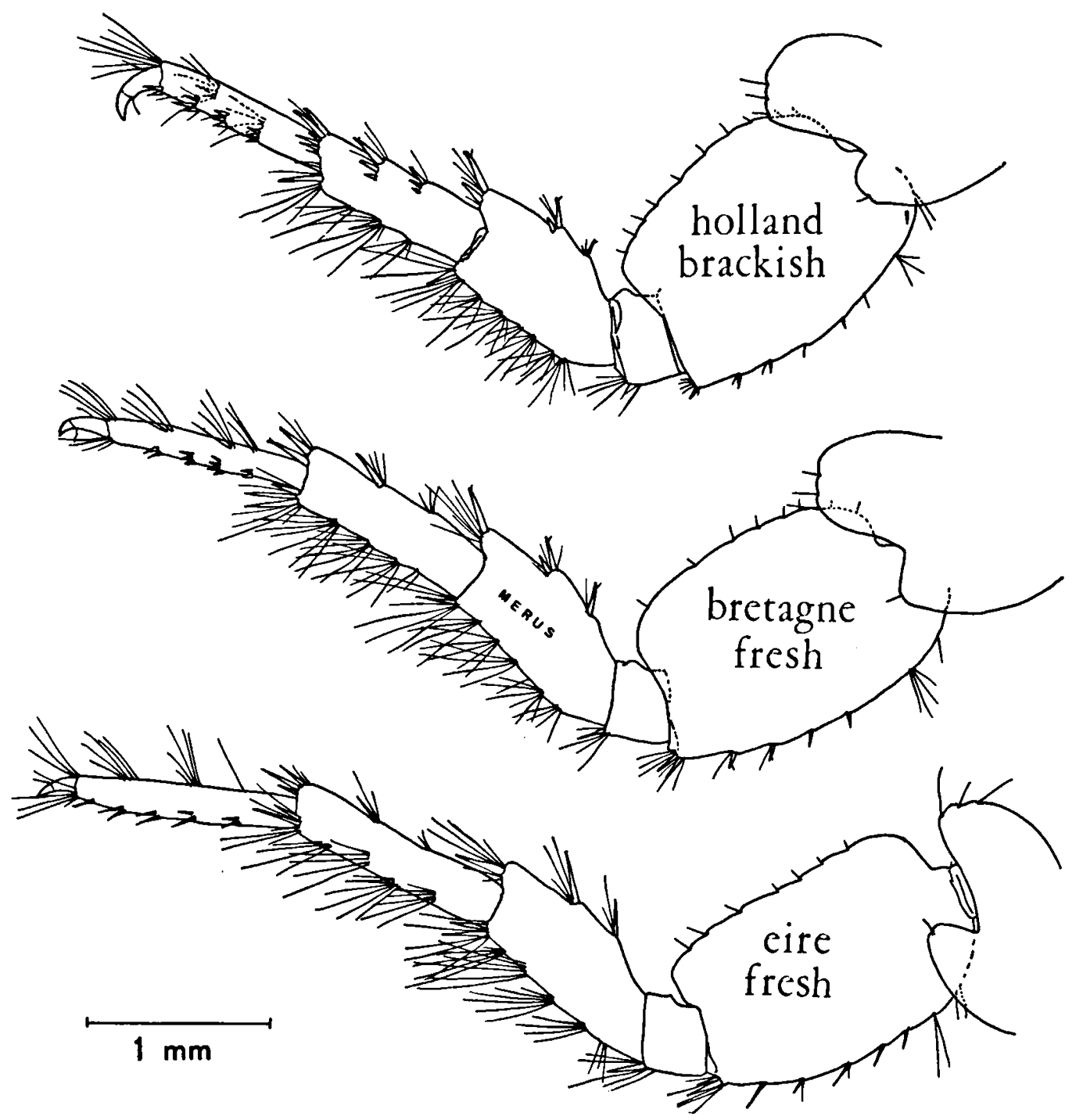

Fig. 14. The fifth leg $(\hat{\delta})$ of individuals of Gammarus duebeni duebeni from brackish waters in Holland (top) and of G.duebeni celticus from fresh waters in Bretagne

reproduce, unless a certain threshold value of the external sodium concentration is reached. Very recently, however, Sutcliffe, 1970, was able to breed the brackish form for more than two years under limnic conditions.

During a short stay at the Station Biologique in Roscoff we did some experiments on the survival of the freshwater form of G.duebeni in 10 to $100 \%$ sea water. These experiments were very imperfect, as they lasted much too short, and only some data on survival after $3,5,7$, and 10 days were obtained. Nothing about the reproductive capacity was observed, though precopulations (middle) and Eire (bottom). Notice the short merus in G. duebeni duebeni.

occurred regularly in the more concentrated media, up to $75 \%$ sea water. ${ }^{4}$ )

IX-2. Our experiments about the survival of $G$. duebeni (Breton freshwater form) brought into more concentrated media can be summarized as follows ( $\mathrm{n}=$ number of animals at the beginning of the experiment):

Mortality rate in $10-50 \%$ sea water: after 3

4) In the hybridization experiments, reported upon in $\S \mathrm{X}$, the freshwater form of $G$.duebeni reproduced successfully in about $3 \%$ seawater. 


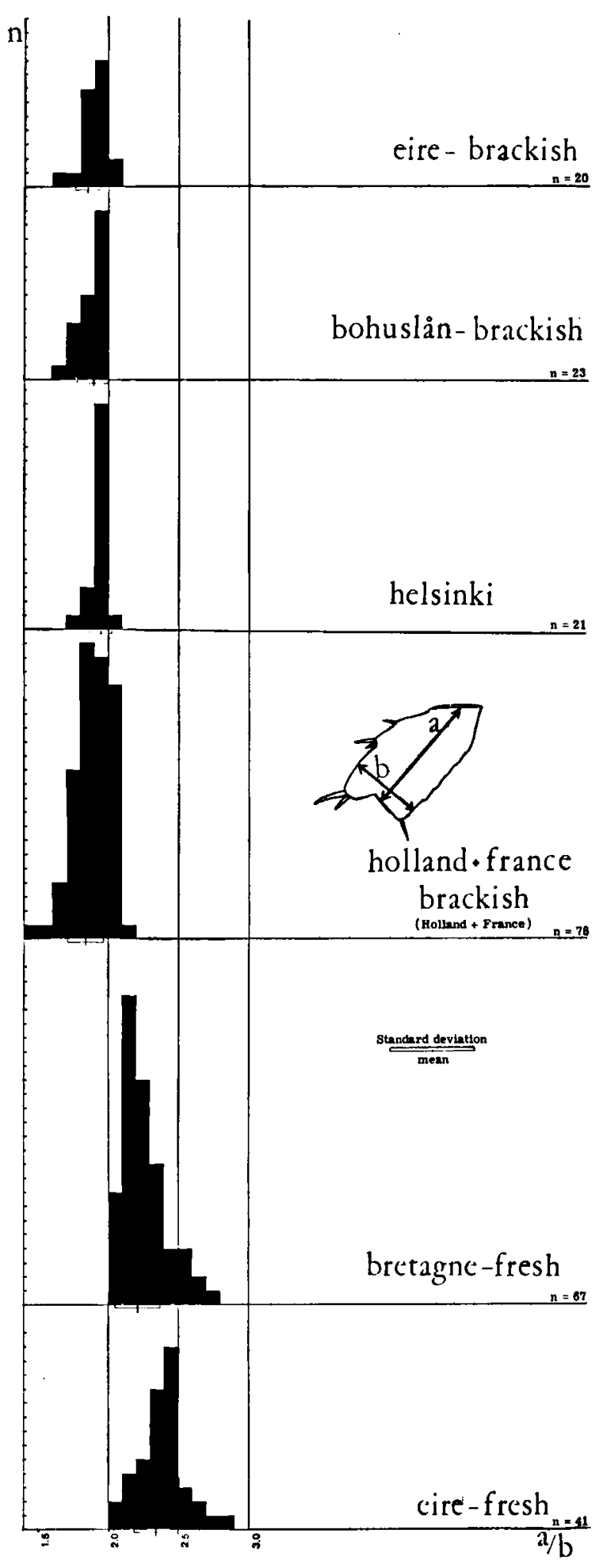

Fig. 15. The length/width ratio $(=a / b)$ of the merus of the 5 th leg in 6 different populations of Gammarus duebeni. The upmost four histograms represent the condition found in brackish populations $(=G$. duebeni duebeni), the two histograms at the bottom represent freshwater populations $(=G$. duebeni celticus). Each square represents one individual. The mean and 1 S.D. on either side of the mean are represented on the absciss.

days $4 \%$, after 5 days $4 \%$, after 7 days $8 \%$, after 10 days $12 \%(n=25)$.

Mortality rate in $50-100 \%$ sea water: after 3 days $13 \%$, after 5 days $20 \%(n=135)$; after 7 days $23 \%(\mathrm{n}=78)$; after 10 days $23 \%$ (n $=30$ ).

Mortality rate in original fresh stream water (from Rivière La Flêche, at Pont-du-Chatel, Na concentration $23 \mathrm{mg} / \mathrm{l}$ ): after 3 days $5 \%$, after 5 days $13 \%$, after 7 days $23 \%$, after 10 days $23 \%(n=39)$.

Admitting the short duration of these experiments, it may be of some importance that the mortality rate in the most dilute (natural) medium is exactly the same as that in the most concentrated medium.

\section{$\S$ X. HYBRIDIZATION OF G. DUEBENI FROM VARIOUS BRACKISH AND FRESHWATER LOCALITIES}

X-1. Although Hynes, 1954: 47 reported on fertile crosses between Gammarus duebeni from a fresh stream and from the saline beach in the Isle of Man, his results are less convincing in the light of Sutcliffe's (1967a : 540) findings implicating that the G.duebeni from streams in the Isle of Man belongs to the same physiological race as the brackish water form. Since Sutcliffe \& Shaw, 1968 , alluded to the possibility that the Irish inland populations might belong to a distinct physiological race, it seemed indicated to repeat the crossing experiments between material from I $\mathbf{r}$ is h fresh waters (and, of course, also from Bretagne) and from some brackish localities.

Such crossbreeding experiments have been carried out in the wintermonths of 1969-1970, with specimens originating from four different localities. Two of these were brackish, the other two limnic. It is conclusively shown, that individuals from these four localities are capable of producing fertile eggs with one another, whichever way the cross is made. 


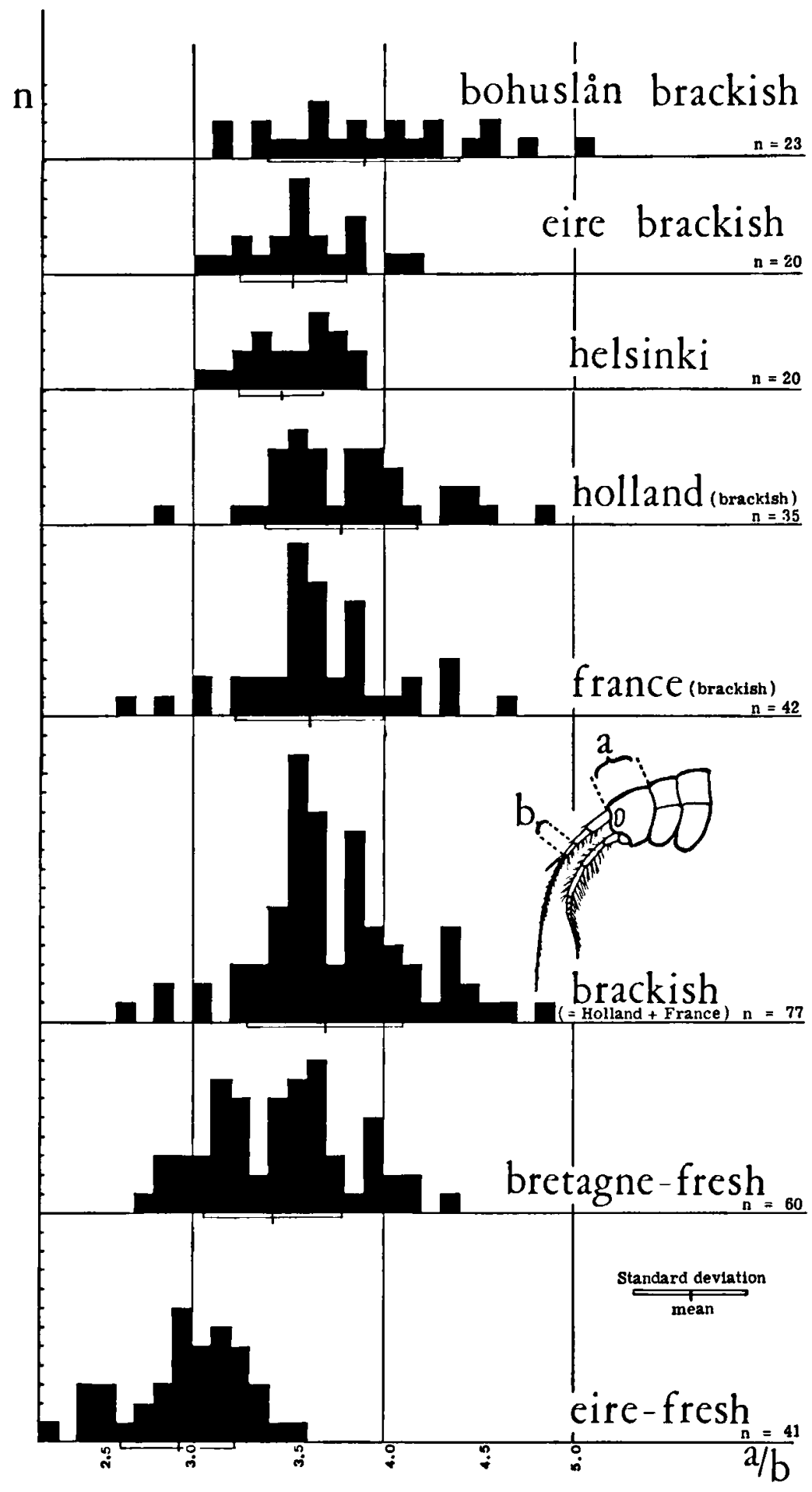

Fig. 16. The ratio cephalic length/length 3 rd segment of A1 in 7 different populations of Gammarus duebeni. From top to bottom: 5 brackish water populations $(G$. d.duebeni), the arithmatic sum of the brackish water populations from Holland and France, and 2 freshwater populations ( $G$.d.celticus). Each square represents one individual. The mean and 1 S.D. on either side of the mean are represented on the absciss. 
X-2. Material. - The experiments have been carried out with $1500-2000$ individuals from each of the following localities:

A) Fresh waters

a) Bretagne, a small stream S.W. of Ploudaniel, near Lesneven (dépt. Finistère-Nord); collected on 22 October 1969 by S. Pinkster and P. Kant; temperature $15.2^{\circ} \mathrm{C}$, pH 7.1, chloride $17.3 \mathrm{mg} / \mathrm{l}$, sodium $19.8 \mathrm{mg} / \mathrm{l}$, calcium 7.3 $\mathrm{mg} / \mathrm{l}$.

b) Eire, Lough Corrib, near the marble quarries on the southern shore of the lough, about 3 miles N. of Galway (Co. Galway); collected 18 November 1969 by J. H. Stock; temperature $7.05^{\circ} \mathrm{C}, \mathrm{pH} 5.5$, chloride $23.0 \mathrm{mg} / \mathrm{l}$, sodium $15.4 \mathrm{mg} / \mathrm{l}$, calcium $79 \mathrm{mg} / \mathrm{l}$, magnesium $5.4 \mathrm{mg} / \mathrm{l}$.

B) Brackish waters

c) France, small wells in the cliff and rockpools at the foot of the cliff at Cran d'Escalles, near Cap Blanc Nez (dépt. Pas-de-Calais); collected 16 October 1969 by H. G. Dennert and M. J. van Maren, temperature $12.2^{\circ} \mathrm{C}$, chloride $1130 \mathrm{mg} / \mathrm{l}$.

d) Holland, IJsselmeer (= former Zuydersea), on the northern slope of the dike from the mainland to the former isle of Marken (prov. North-Holland); collected on various days in November and December 1969 by J. H. Stock and S. Pinkster; temperatures $7.1^{\circ}-0.3^{\circ} \mathrm{C}$, chloride $280-580 \mathrm{mg} / \mathrm{l}$.

$\mathrm{X}-3$. Methods. - The experiments were done in the Institute of Taxonomic Zoology, Amsterdam, in a room with indirect, diffuse daylight and temperatures slightly above, but fluctuating with the outside air temperatures.

The animals from abroad were transported by road or by air to Amsterdam in plastic bags, containing 200 specimens each in $500 \mathrm{~cm}^{3}$ natural water, under oxygen in a cooling jug (temperature $0^{\circ}-5^{\circ} \mathrm{C}$ ).

In the laboratory, the animals were kept in plastic storage basins of $25 \times 25 \times 10 \mathrm{~cm}$, in 3 to $5 \mathrm{~cm}$ of water, under aeration. Some pebbles were added for shelter. About 200 specimens were kept in each basin. The water in the basins corresponded in composition with the water from which the animals originated. The animals were fed with Stellaria media Vill., a weed that was easily available in all seasons. It is eaten completely by the gammarids, leaving neither "skeleton" nor slimy bacterial growth.
In the storage basins, sexually active individuals formed readily precopulae. Such precopulated couples were separated and all females were checked as to the absence of eggs. The absence of eggs is a sufficient proof that fertilization has not yet taken place.

The precopulated males from one population were brought together with precopulated females from another population, and vice versa. Some 10 to 20 heterogeneous sets of animals were put together in the same plastic basins as mentioned above, in natural water of one of the two sexes. The number of animals used in the experiments was largely variable, depending on the number of precopulae available at a certain moment. The heterogeneous animals usually resumed the precopulated position very soon (often within seconds after being brought together). As soon as the females of such couples produced eggs, they were isolated in smaller plastic basins, $7 \times 7 \times 10 \mathrm{~cm}$, again in $3-5 \mathrm{~cm}$ of water. Once hatching of the eggs occurred, the "empty" females were removed, in order to save the juveniles from being devoured by their mother.

Since the temperature in the experimentation room fluctuated widely (from $2^{\circ}-15^{\circ} \mathrm{C}$, maximum daily change of $8^{\circ} \mathrm{C}$ ), the incubation period, which is dependent on temperature, varied also largely.

X-4. Results - All possible crosses were fertile (see table VI). The percentage of females producing an offspring varied from 10 to $15 \%$ in homogeneous ( = intrapopulational) crosses, and from 7 to $35 \%$ in heterogeneous ( = interpopulational) crosses. The low percentage of successful crosses, also in homogeneous couples, is most probably due to unfavourable temperature conditions in the experimentation room. Since the overall daily mortality rate in fertilized females was about $2 \%$, after 50 days all ovigerous females were dead. At the low temperature present in the experimentation room in the earlier experiments (November and early December), the development of the eggs took so long, that a great percentage of the ovigerous females died before hatching their eggs. Later (late December and January), the fertilized females were placed at about $15^{\circ} \mathrm{C}$; the duration of the development of the ova is then much shorter, and as a result, higher numbers of successful crosses were obtained.

The water composition in the experimentation basins has in general little influence on the results. There is, however, one - probably meaningful - 
Table VI

Summary of the crossbreeding experiments between individuals from different populations of $G$. duebeni (br. = brackish).

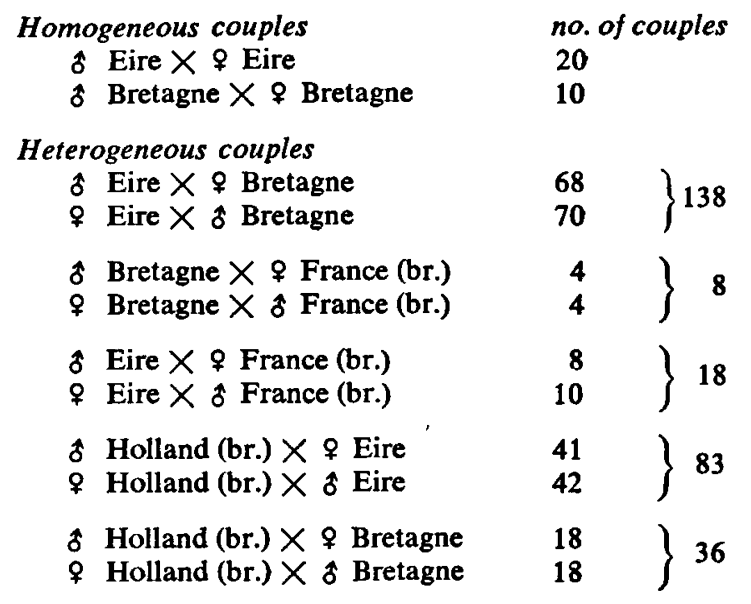

no. of +9 producing offspring
3
1

$\left.\begin{array}{l}2 \\ 8\end{array}\right\} 10$

$\left.\begin{array}{ll}1 \\ 1\end{array}\right\} \quad 2$

$\left.\begin{array}{l}2 \\ 2\end{array}\right\} 4$

$\begin{array}{rrr}3 & & 29 \\ 1 & \\ 8 & \} & 9\end{array}$ exception: crosses between brackish water animals and individuals from fresh waters (Eire or Bretagne) were more successful in brackish water than in fresh water. Of 24 crosses attempted between brackish animals and limnic animals, only 1 produced an offspring in the medium poor in ions. Of 110 similar crosses in media rich in ions, 44 were successful.

This difference is highly significant, of course, but we bear one reservation in mind in interpreting these observations: the experiments in media poor in ions have been done largely in November and December, whereas - as explained above- experiments in these months had a lower incidence of success than the January crosses. This fact may have influenced (but does not completely explain) the failure to obtain an offspring in crosses between brackish and fresh water animals with fresh water as medium.

At any rate, the failure to obtain such an offspring, is in agreement with Reid's (1939) and Hynes' (1954) observations that brackish water individuals of G.duebeni do not produce fertile eggs in culture media poor in ions.

The greatest difficulty encountered in mating experiments is that individuals from the different populations showed differences in the reproduction period. So, in October and November, the freshly caught limnic individuals (from Bretagne and Eire) reproduced actively, but hardly any sexual activity was observed at that period in the brackish water populations, which started reproducing in December, having optimal sexual activity in January.
In the light of the size differences that exist between males and females on the one hand $(\delta>\uparrow)$, and between individuals of different populations on the other hand (Holland - brackish and France - brackish $>$ Eire $>$ Bretagne), one more conclusion from table VI seems obvious: the larger the size difference between males and females in a crossbreeding experiment the less chance on fertilization. So, the crosses with the greatest size difference between the partners are $\delta$ Eire $\times \&$ Bretagne, $\delta$ France (brackish) $\times q$ Bretagne, $\delta$ France (brackish) $\times \$$ Eire, $\delta$ Holland (brackish) $\times \&$ Eire, and $\delta$ Holland (brackish) $\times \&$ Bretagne. In these crosses, 141 couples were involved, of which only 9 produced an offspring. In the reciprocal crosses, thus those with less difference in size between the partners, 145 couples were involved, of which 45 produced an offspring. This difference is highly significant $\left(P_{R}<0.0005\right)$.

\section{§ XI. GAMMARUS DUEBENI DIVIDED INTO TWO SUBSPECIES}

XI-1. In the light of the distinct morphology ( $\S$ VII-6), the distinct physiology (Sutcliffe \& Shaw, 1968), and the distinct ecology of the brackish water "form" and the freshwater "form", Stock \& Pinkster, 1970, decided to evaluate the suggestion of Reid, 1939 and to describe the two "forms" as different subspecies.

As the nominal subspecies, they have - in accordance with the recognized usage - indicated the brackish water form. Moreover, this usage is in agreement with the fact that from the type 

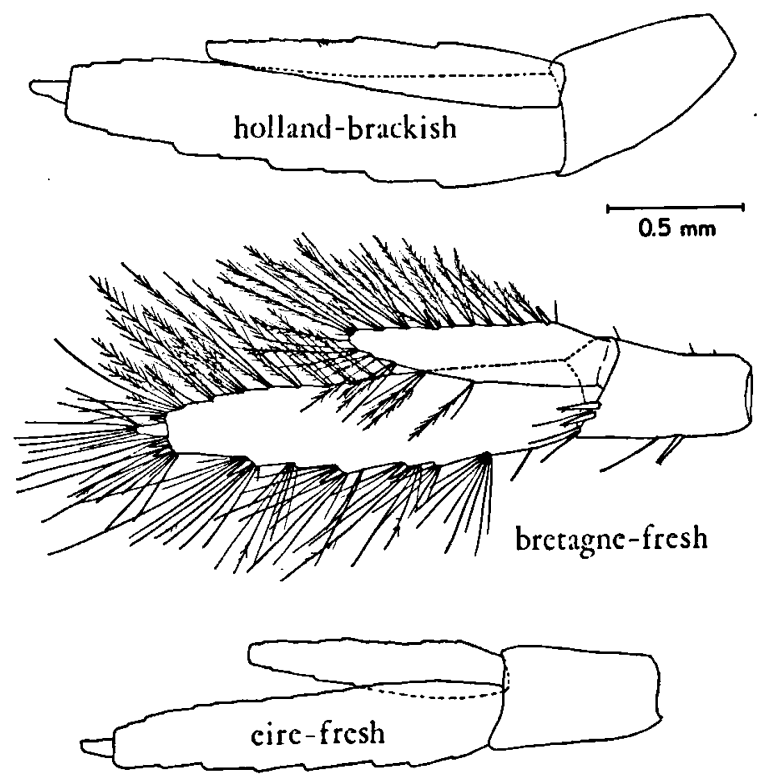

Fig. 17. Third uropods ( $\hat{o}$ ) of Gammarus duebeni duebeni from brackish waters in Holland (top), and of $G$. duebeni celticus from fresh waters in Bretagne (middle) and Eire (bottom). Although the relative length of the endopod is very variable, specimens from fresh waters, especially in Bretagne, tend to have shorter endopods than in brackish water populations.

area only that form is known, and with the morphology of the neotype (see $\S$ VIII-2).

The nominal subspecies has a wide distribution from the White Sea to Bretagne, always in coastal localities.

The freshwater form is restricted to the southernmost part of the distribution area of $G$. duebeni and has been recorded from inland waters in Ireland and Bretagne.

\section{XI-2. Diagnoses}

G. duebeni duebeni Liljeborg, 1852.

Merus of 5th leg at most twice as long as wide. In brackish to hypersaline, coastal waters, or in near-coast fresh waters with a raised sodium content. Restricted type-locality: Stora Kalsöy (an exposed little island, about $25 \mathrm{~km} \mathrm{~S}$. of Bergen, Norway), in supralittoral rockpool. From this locality, a male specimen has been chosen as neotype; it has been deposited in the Zcölogisch Museum, Amsterdam, under cat. nr. Amph. 102.369.

G. duebeni celticus Stock \& Pinkster, 1970

Merus of 5th leg at least twice as long as wide. In fresh, inland waters (Ireland and Bretagne).
Type-locality: Lough Corrib, 3 miles N. of Galway, Co. Galway, Eire. Holo- and paratypes are deposited in the Zoölogisch Museum, Amsterdam, cat. nr. Amph. 102.370.

\section{$\S$ XII. DOES THERE EXIST AN ISOLATING MECHANISM BETWEEN THE TWO SUBSPECIES?}

XII-1. As shown in a previous paragraph $(\S \mathrm{X}-4)$ the freshwater and the brackish water race are fully interfertile. Nevertheless, in nature the physiological and morphological differences between the two races are maintained, indicating that there is little gene flow only. This raises the question what barrier isolates the two subspecies to prevent too much gene flow.

XII-2. Although Reid's, Hynes' and other experiments seemed to demonstrate that the brackish race cannot successfully breed in fresh water with a low ion content, Sutcliffe (1970) could adapt it

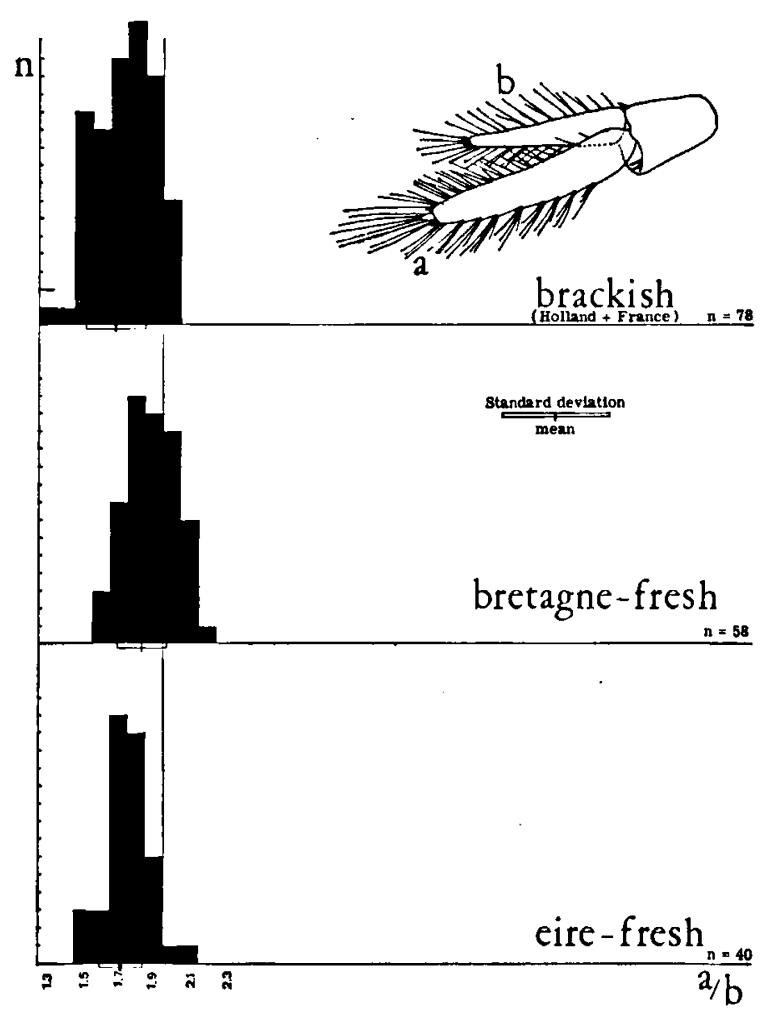

Fig. 18. The ratio length exopod/length endopod of the 3rd uropod in three different populations of Gammarus duebeni. Top: a brackish water population (G.duebeni duebeni). Bottom: two freshwater populations (G. duebeni celticus). Each square represents one individual. The mean and 1 S.D. On either side of it are represented on the absciss. 
to limnic conditions. The freshwater race as well is capable of reproducing in a brackish environment. Moreover, we noticed occasionally in Bretagne, that G. duebeni shows a certain amount of downstream drift (perhaps it is only carried away passively with the river current), and that it can be carried this way into estuarine regions. Nothing would then prevent such individuals to mate with members of the brackish water population. However, the number of individuals drifting downstream is very small (not at all comparable with the large numbers of G. zaddachi and G. chevreuxi found in drift nets), and it is concluded then that downstream drift certainly is not a frequent phenomenon in G. duebeni.

So, it remains theoretically possible that freshwater populations of G.duebeni, living in the more upstream reaches of a river, are in constant contact with estuarine populations. Microgeographic analyses in Breton streams flowing directly into the sea have been made in very few cases only by our team. An exception forms a small stream W. of Roscoff, called l'Horne, where one of our team members, Mr. H. G. Dennert, took samples every few hundred yards. These samples did not reveal a direct contact between the freshwater populations of $G$. duebeni (which were confined to the upper courses, and the adjacent part of the middle course, of the river) and the estuarine populations (which were confined to the mouth of the stream, where it occurred under cobbles of the river bed, above high neap-tide level). In between these two stretches, thus in the lower middle course of the river, two other species of gammarids were found, viz. $E$. berilloni in the fresh part, and $G$. zaddachi in the more seaward part. Since Kinne reported the latter to be strongly competing with $G$. duebeni, the absence of duebeni in the zone of zaddachi is not surprising.

Consequently, there are indications that the freshwater populations are effectively cut off from the brackish populations, by a zone of other gammarids in between. More microgeographic work must be done, however, to confirm or to disprove this idea.

Certain is, that in stream systems where both G. duebeni celticus and E. berilloni occur, the former is always confined to the upper reaches and smaller tributaries of the system, where it coexists (and probably can successfully compete) with the latter, whereas the latter is the only species present in the middle course of the main stream (see $\S \mathrm{V}-4$ ).
XII-3. There might exist another, partial, isolation mechanism between G. duebeni duebeni and $G$. duebeni celticus, viz., a seasonal reproductive barrier, in the sense that the latter reproduces in a period of the year in which the former is not sexually active.

Support for this idea is found in the observations of Kinne, 1952a, Hynes, 1954, and Steele \& Steele, 1969, corresponding fully with those of our own, according to which a strong decline or a total stop in the reproduction of $G$. duebeni duebeni takes place from July or August to November or December. These observations have been made on populations from Germany, The Netherlands, northern France, and Great Britain. ${ }^{5}$ )

On the other hand, our team observed in Bretagne G.duebeni celticus actively reproducing during the period from September to early March, thus in part during the "closed" period of $G$. duebeni duebeni (no observations are available from the rest of the year).

In laboratory experiments also (see $\S X-4), G$. duebeni celticus (both from Eire and from Bretagne) was sexually active earlier in autumn than $G$. duebeni duebeni.

A difficulty in interpretation of these data is, that the reproduction period, temperature dependent as it is, almost certainly does not fall always in the same time of the year in different geographic regions. It would be correct then to compare Breton G. duebeni celticus with Breton $G$. duebeni duebeni, or Irish populations of the two subspecies with one another. At present, the observations on the period of sexual activity are too scanty to allow such a comparison.

So, we do possess only two observations on the reproduction of G. duebeni duebeni in brackish conditions in Eire or Bretagne. In September 1969, G. duebeni duebeni was not sexually active in western Bretagne. In a brackish Irish rockpool, just above $\mathrm{H} \mathrm{W} \mathrm{S}$, this subspecies was found reproducing on 18 November 1969 , at a water temperature of $10.95^{\circ} \mathrm{C}$.

The only published data on the reproduction of Irish G. duebeni celticus are those obtained in a laboratory experiment by Dr. W. E. Frost (see Hynes, $1954: 76$ ), recording sexual activity from the middle of May to early July. In addition, our

5) However, no autumn stop in sexual activity was found in a population of G.duebeni (belonging, according to Sutcliffe's sodium regulation findings, probably to the nominal subspecies) living in a stream on the Isle of Man (Hynes, 1954). 
own team observed reproducing fresh water populations in Eire from the middle of November to early January. Unfortunately no observations are available from the other months of the year.

\section{§ XIII. DISCUSSION}

XIII-1. Hynes (1954, 1955a) brought forward the hypothesis, that G.duebeni was formerly widespread in fresh waters in western Europe and that it is now being eliminated from freshwater through competition with $G$. pulex. In this concept, $G$. duebeni was (and still is) pushed into the brackish belt by invading G.pulex. On the other hand, Sutcliffe (1967a) gives a complete reversal of this suggestion, viz. that $G$.duebeni may be in the process of colonizing fresh waters, and that it may gradually extend its range into suitable streams, thus resembling the brackish water snail Potamopyrgus jenkinsi (Smith), which recently invaded fresh waters in western Europe (Hubendick, 1950; Warwick, 1952; Hunter \& Warwick, 1957; Todd, 1964).

XIII-2. Sutcliffe based his suggestion on the following observations:

(a) G. duebeni is widespread in mixohaline coastal waters. With the exception of its range in Ireland, its distribution in freshwaters is restricted to habitats with a relatively high salt concentration. Such "freshwater" localities are always close to exposed coasts, and it seems likely that they are provided with salts from the seas carried inland by autumn and winter gales.

(b) Through natural selection of individuals with a sodium uptake rate higher than the average, gradually freshwater populations can be built up. Such freshwater populations thus retain a high blood concentration when under limnic conditions, but since they are still quite able to survive in full-strength sea water, it is likely that they originate from the sea, rather than that competitors push them into a new, hostile, peripherous environment, such as the sea.

(c) With the exception of its vast distribution in Eire, G. duebeni has only a very localized distribution in fresh water with a high salt content; the latter ecological factor determines, that no other competing species can enter into these waters. This very localized distribution leads to the suggestion that this is due to very recent colonization from the sea into an open niche.

(d) The absence of G. pulex in streams occupied by $G$.duebeni, but especially its absence also in adjacent streams (still) free of G.duebeni, makes it more probable that $G$. duebeni is invading an open niche, rather than that $G$.pulex and $G$. duebeni show interspecific competition.

XIII-3. Let us consider these arguments one by one, in the light of the data obtained in the previous chapter on the distribution of various gammarids in western France.

(a) G.duebeni is a common species in western Bretagne, and is not restricted to near-shore localities. It occurs in numerous freshwater stations, with a low salt concentration, and thus behaves just like Irish populations of $G$. duebeni.

(b) Our own experiments, summarized in § IX-2, clearly support Sutcliffe's conclusion, that individuals from freshwater populations of G.duebeni can easily be brought into water with a higher ion content, and even into full strength sea water, with little ill effect. In such salt waters even precopulation can take place.

(c) In western France, the situation is completely identical to that found in the British Isles and Ireland: G. duebeni shows a vast inland distribution in Bretagne (as in Eire), but is otherwise localized to very restricted near-shore areas, where the winds carry much salt into the water.

So far, we are in complete agreement with Sutcliffe's suggestions, but as to point d, the alleged abserce of competition, we can only partly agree. (d) It is not true that in French near-shore waters, which have a relatively high salt concentration, the true freshwater gammarids cannot penetrate. This is particularly clear on the exposed, peninsular west coast of Normandy, where G. pulex was found in several localities with 40 or more $\mathrm{mg}$ sodium per 1 (highest sodium concentration observed $58 \mathrm{mg} / \mathrm{l}$ ), and $E$. berilloni in two localities with 41 and $43 \mathrm{mg}$ sodium per 1. G. duebeni was not found in these Normandian waters.

Sutcliffe's suggestion that G. pulex might not be able to penetrate in waters with a raised ion content, comes in serious conflict with several pertinent observations in the literature, recording the ability of G.pulex (and of other freshwater gammarids) to live - both under experimental and under natural conditions - in salty waters.

So, Schmidt, 1913, found G. pulex in mineral springs at Salzkotten in Germany, in waters with salinities ( $=$ total amount of dissolved salts) of $5615-25370 \mathrm{mg} / \mathrm{l}$. The locality was revisited by some members of our team in 1968 and G. pulex 
was still found to be present; the 1968 analysis showed the presence of the amphipod in mineral waters with chlorinities up to $4000 \mathrm{mg} / \mathrm{l}$. Von Alten (1915) records $G$. pulex from the Salzbach near Witzenhausen (Germany) at a salinity of $5500 \mathrm{mg} / \mathrm{l}$, and from the Schunter at $1000 \mathrm{mg} / \mathrm{l}$.

Vincent, 1966, has shown experimentally, that G. pulex shows "normal activity" in more concentrated media up to $30 \%$ sea water ( $=$ approx. $10.3 \% \mathrm{~S}$, or $3200 \mathrm{mg} \mathrm{Na} / \mathrm{l}$, or $5880 \mathrm{mg} \mathrm{Cl} / \mathrm{l}$ ). These values compare fairly well with the concentrations found in natural saline waters inhabited by $G$. pulex.

More or less similar results were obtained by Oswald, 1905: 169, who found no ill effects neither in diluted seawater of $11.8 \%$ S. The first toxic effects were observed by him at salinities of $18.90 \%$ and higher.

Schmitz (1959) and Schmitz, Besch \& Kneissl (1967) report also upon the salt tolerance of $G$. pulex, and show convincingly that adaptation to higher concentrations is quite well possible.

Similar adaptations - whether genetic or nongenetic is unknown - to more concentrated media have been found in nature in another freshwater species, Gammarus fossarum, a healthy population of which was observed by Stock, Nijssen \& Kant (1966:23) on the open, exposed beach of the French Channel coast $\mathrm{N}$. of Boulogne, where the chlorinity (at fine weather and neap-tide) was $231 \mathrm{mg} /$ l. Moreover, Vincent (1966) reports upon Echinogammarus berilloni withstanding experimentally even very concentrated media, viz. up to $80 \%$ sea water (= approx. $14080 \mathrm{mg} \mathrm{Cl} / \mathrm{l}$ ).

All these observations point into one direction: the so-called "freshwater" species can survive and thrive in mixohaline waters without difficulty, provided that competitors are absent.

We also reject Sutcliffe's suggestion, that there is no interspecific competition between G. duebeni and G. pulex. Our observations in Bretagne, based on 364 sampling points where gammarids were present, showed the species composition recorded in table IV. Although G. pulex and G.duebeni are sympatric in a considerable area (see figs. 1, 2 ), there is a surprisingly low incidence of joint occurrence of G.pulex and G.duebeni, viz. in 4 stations $(1.1 \%)$ only. Joint occurrence of $G$. pulex and $E$. berilloni is much more frequent ( 56 stations or $18 \%$ of the stations in Bretagne, 30 stations or $46 \%$ in. Normandy), and also joint occurrence of G. duebeni and E. berilloni is significantly greater (20 stations or $5.5 \%$ ).
The only plausible explanation for these figures appears to be the assumption that G.duebeni and $G$. pulex do strongly compete, whereas $E$. berilloni is not involved in a strong interspecific competition with G. pulex and in a mild competition only with $G$. duebeni. This assumption is, as far as $E$. berilloni is involved, affirmed by the distribution of that species in a stream near Ambleteuse on the French Channel coast, recorded by Stock, Nijssen \& Kant, 1966. There, G. pulex and G. fossarum are confined to more or less well-defined stretches of the stream, only showing a slight overlap in distribution, whereas E. berilloni completely overlaps the zones of either of these two Gammarus species, and is apparently not involved in a strong competition with either of them.

It might be remarked here as a sideline, that one has to sample very intensively to demonstrate joint occurrence of pulex and duebeni, and that there is a great chance that when sampling is done in less than 100 stations, no joint occurrence at all is found.

XIII-4. On the other hand, we can agree with Sutcliffe's assumption, that G.duebeni's presence in near-coast fresh waters is due to fairly recent colonization. We assume, as explained in the sequel (§XIII-6) that G.duebeni entered into these coastal fresh waters just in postglacial times (i.e., less than 10.000 years ago).

XIII-5. Summarizing, it can be said that there are certain arguments in favour of Hynes' theory, but also some other arguments that tend to support Sutcliffe's ideas.

XIII-5-1. Pro Hynes plead the following aguments:

(a) There is apparently strong competition between G. pulex and G.duebeni (this paper § V-3, $\mathrm{V}-4)$.

(b) G. pulex evidently is a species that had its refugia during the glacial periods somewhere "in the East", and that is invading now western Europe (the absence of pulex s.str. in northern Scandinavia, Spain and Italy, and the wealth of pulex-like forms in the Balkans and further East prove this convincingly).

Against Hynes' theory pleads, as Sutcliffe emphasized:

(a) G. duebeni from brackish waters do not breed in fresh waters, but freshwater duebeni does reproduce in brackish media. If G. duebeni originally was a freshwater species, it would 
- even after being chased away from inland waters by $G$. pulex - be able to reproduce under experimental conditions in its original medium.

(b) In localities where G.pulex (still) is absent, $G$. duebeni is (still) present in fresh waters. In these areas, however, G.duebeni is not yet forced - through competition - to evade to peripherous niches, consequently these niches should (still) be free of G.duebeni. Now, the actual situation, both in Bretagne and in Ireland, is that great inland populations of $G$. duebeni are present, whereas at the same time G. pulex is absent (although a zone of sympatric occurrence is present in Bretagne). But at the same time also brackish populations are present (abundant in estuaries and rockpools in Eire, rare in estuaries and absent in rockpools in France). It is difficult to see why G. duebeni should migrate into a peripherous suboptimal niche in absence of competition.

XIII-5-2. Pro Sutcliffe are the following arguments:

(a) The arguments (a) and (b) contra Hynes.

(b) The limited distribution of G. duebeni in nearcoast fresh waters, e.g., in southern Britain and in Norway.

(c) The sodium regulation mechanism in brackish and freshwater populations.

Contra Sutcliffe are:

(a) The obvious presence of competition between G. pulex and G. duebeni in Bretagne.

(b) The ability of G.pulex to penetrate into waters with high salt contents.

(c) A very recent invasion of G.duebeni into freshwater does not fit with the morphological differentiation (on subspecies level) observed in Irish and Breton G. duebeni. The evolution of both morphological and physiological features in these populations of $G$. duebeni point to a certain lapse of time necessary for the acquisition of such features.

(d) The microgeographical evidence presented in this paper $(\S \mathrm{V}-4)$.

XIII-6. Our ideas about the origin of freshwater populations of $G$.duebeni

It thus appears that both Hynes' and Sutcliffe's theories, although each supported by some evidence, meet with serious objections in other fields. We have made an attempt to construct a historical zoogeographic picture, explaining all presently available facts, and not contradicting any piece of available evidence.

(1) It is assumed that G.duebeni was, in preglacial periods, a marine cold-temperate species inhabiting the tidal belts of the coasts of northern Europe and eastern North America.

In the tidal belt, salinity conditions can vary enormously, due to rainfall and evaporation, and some authors (e.g., Dahl, 1959) even classify the littoral zone ecologically within the scale of poikilohaline waters. The species still prefers coldtemperate conditions, as is shown by its distribution pattern: shores up to Greenland and the White Sea; avoiding too warm niches, like rockpools, at the southern end of its distribution area, i.e., in Bretagne; reproducing in brackish waters in the winter. The species is still restricted to very shallow waters, where it lives from the mid-tidal zone to the very edge of water and land (see e.g. Den Hartog, 1964).

From these facts, the original, preglacial $G$. duebeni arises as a cool-temperate, euryhaline, littoral species, cold stenotherm in the reproduction period, eurytherm outside the reproduction period.

(2) In the glacial periods, practically no inland waters were present, but larger waterbodies were dammed up against the icewalls occasionally. Most of these waterbodies were presumably brackish, from salts expulsed by the freezing of the ice, and from contact with sea water in coastal areas. In these cold, brackish, dammed up glacial lakes, G. duebeni may have had a wide distribution during the glacial periods.

(3) In the Mindel-Riss interglacial period, the melting ice sweetened the waters at the edge of the ice cover, and the populations of G.duebeni living in these waters got gradually adapted to the lower ion content.

(4) In this interglacial period, such adapted $G$. duebeni populations could easily invade fresh, inland waters, but they did not get enough time to become - morphologically or physiologicallyfully adapted to the freshwater habitat, since they were expelled again from it in the Riss and Würm (= Illinoian and Wisconsin) glacial periods, at least from fresh waters in the areas glaciated at these periods, i.e., from Scandinavia, the greatest part of Great Britain, and the northern part of Germany and Holland. In areas not glaciated during the Riss and Würm glacials, inland freshwater populations of G. duebeni could be maintained, and could adapt themselves gradually better 


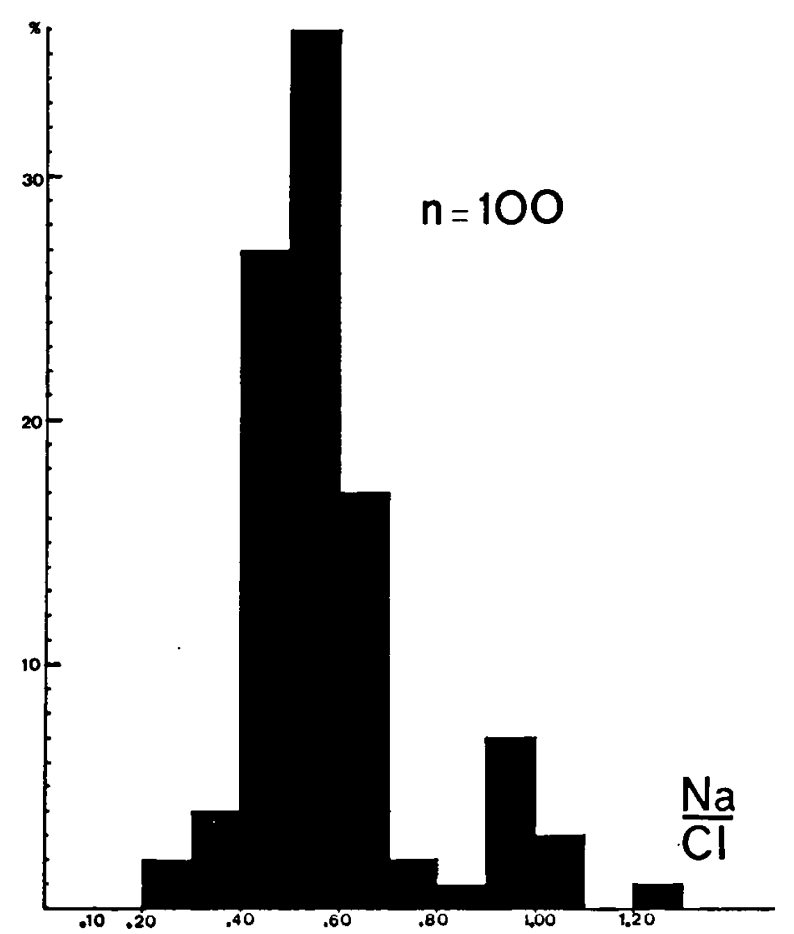

Fig. 19. The ratio sodium/chloride, both expressed in $\mathrm{mg} / \mathrm{l}$, for 100 freshwater stations of Gammarus duebeni in Bretagne. The mean of these 100 analyses is 0.58 , which is very close to the mean $\mathrm{Na} / \mathrm{Cl}$ ratio of $0.51-0.56$ occurring in normal sea water (see also $\S \mathrm{VI}-4$ ).

to this environment. These non-glaciated inland waters occurred along the southern boundary of the species' distribution area, in particular in coastal refugia in Ireland and along the Atlantic coast of France (and perhaps also in southern England).

It should be borne in mind that southwestern England, Ireland and Bretagne were not separated in the Riss glacial by sea, but formed one coherent coastline together.

(5) Point 4 explains the presence of freshwater populations in areas not glaciated since the Mindel glacial period (or never at all glaciated), and the acquisition of characteristic, subspecific features by these populations. The time elapsed since the Mindel glacial period (some 425.000 years, see De Lattin, $1967: 314$ ) seems sufficiently long to account for subspecific differentiation.

It also explains the absence of freshwater populations of G.duebeni in areas that were covered by ice in younger periods, viz., in the Riss and Würm glacials. Since the Würm glacial period is over for 10.000 years only, it is clear that no extensive adaptation to fresh waters was possible in this short lapse of time in Scandinavia and Scotland.

(6) Nowadays, like in Mindel-Riss interglacial period (= Yarmount interglacial period), one sees again infiltration of $G$. duebeni into freshwaters, but these new invaders have not yet acquired the morphological or physiological adaptations, present in the older migration waves inhabiting Bretagne and Ireland. Such recent invasions account for the presence of $G$.duebeni in certain near-coast freshwaters in England, the Isle of Man, Scotland, and Norway. They are helped by the fact that near-coast localities usually have a higher salt content than inland waters, the salts being blown in by gales from the sea. (The mean ratio $\mathrm{Na}: \mathrm{Cl}$ in inland Breton waters is very close to the mean ratio of these ions in sea water, see fig. 19.)

(7) In the postglacial period, other freshwater gammarids spread from their refugia in the warmer parts of Europe into the deglaciated open niches. One of these species, G. pulex, reached England in time, before the break-through of the English Channel, but failed in reaching in time Ireland. So, in Ireland we find $G$.duebeni as practically the only inland species (in some restricted localities along with another glacial relict, G. lacustris).

(8) Competition between G. pulex and G. duebeni seems pretty obvious from the data presented in this paper. Apparently G. duebeni is the loser of this competition in fresh, running waters. In waters with a higher ion content, both species occasionally coexist (see Den Hartog \& Tulp, 1960), but usually $G$. duebeni is in the advantage there.

(9) In certain non-glaciated areas in western France, like Normandy, G.duebeni presumably was present after the Mindel glacial period, but is now (=1969) entirely replaced by $G$. pulex migrating from the East. There is an indication, that $G$. duebeni was eliminated through competition from Normandy very recently only. As a matter of fact, there exist two older papers recording G.duebeni from fresh, inland Normandian waters, viz. of Chevreux \& Fage, $1925: 257$, and of Pacaud, 1952 : 99. Chevreux \& Fage mention a well-defined locality, "ruisseau le Dic, eau douce". We have sampled this locality in 1969 and found only G. pulex in it. Pacaud is much less specific, stating merely: "En France, ce Gammare est fréquent, en eau douce comme en eau saumâtre, en Normandie et en Bretagne". Though Pacaud apparently intended to introduce his records on a distribution map (map 1 on page 97), 
as can be deduced from the caption ("observations anciennes" and "observations nouvelles"), the map does not bear this intention out; Pacaud's sudden death no doubt prevented him completing the map.

Not in agreement with Chevreux \& Fage and with Pacaud is Legueux's study (1927) on the freshwater gammarids of Normandy, recording $G$. duebeni from two brackish localities only, whereas she found G. pulex "dans toutes les rivières où il m'a été possible de pêcher" (1927: 38). This situation agrees with that found during the 1969 samplings.

(10) In Bretagne, G. pulex is still in the process of moving to the West. There is a narrow overlapping zone where both G.duebeni and G. pulex occur. Microgeographic studies show that though there are several stream systems where both species exist, there are very few stations where they really occur simultaneously. In all cases examined, G. duebeni is restricted to the very upmost reaches of the streams, thus to the swampy spring regions, whereas it is replaced by $G$. pulex further downstream. Now, if G.duebeni was migrating inland, as Sutcliffe postulated, just the reverse situation would be true.

(11) In the westernmost part of Bretagne, not yet reached by $G$. pulex, G. duebeni still inhabits all kinds of waters: springs, upper, middle and lower courses of streams, and lakes; in the part of Bretagne reached already by $G$. pulex, G. duebeni shows a relict distribution, being pushed back into the uppermost parts of the brooks.

\section{$\S . X I V$. ACKNOWLEDGEMENTS AND RESPONSIBILITIES}

The authors are indebted to the Station Biologique, Roscoff, France, where our team received hospitality during the fieldwork. Many thanks are due to the enthusiastic team of M.Sc. students, without whose help it would not have been possible to sample 642 stations, and to analyse the water composition at these stations. The following students participated in this project: Mr. K.E. Bakker, Mr. F. A. J. van den Beld, Mr. J. W. Bleijs, Mr. J. N. de Boer, Miss A. van Buren, Mr. H. G. Dennert, Mr. M. F. W. Dubois, Mr. R. Dijkema, Miss J. E. M. van Eekeres, Miss J. M. J. F. Gras, Mr. A. M. Hak, Mr. F. Icke, Mr. P. P. A. M. Kop, Mrs. F. M. Kop-van Gestel, Mr. W. M. van der Leeuw, Mrs. C. C. M. van der LeeuwLeegwater, Miss A. M. J. Maasen, Mr. T. Sluiters, Mr. D. H. Vonk.

Furthermore, we wish to acknowledge grants from the University of Amsterdam to the M.Sc. students for the fielwork in Bretagne, and from the Netherlands' Organization for Pure Scientific Research (Z.W.O.) of The Hague to the senior author (J.H.S.) for obtaining live Irish material. Thanks are also due to the Laboratory of Animal Physiology of the University of Amsterdam for placing a flame spectrometer at our disposal (and for the cooperation of Miss $\mathbf{H}$. Kleijn in running this apparatus); to Drs. S. Segerstråle of Helsingfors, R. Olerod of Stockholm, A. Holm of Uppsala, and E. Dahl of Lund, for the loan of, or information on, Scandinavian material. Mr. W. Vader, M.Sc., of Bergen, Norway, kindly provided several Norwegian samples, including topotypes.

Additional samples, used in our microgeographic analyses $(\S \mathrm{V}-4)$ were collected by $\mathrm{Mr}$. J. Paul, Mr. H. G. Dennert, and Miss M. J. van Maren. Mr. H. Olofsen and Dr. W. Balk (both of Amsterdam) gave valuable advices in statistical problems.

Although the present paper is, we hope, a unity, each of the authors took special care for certain sections of it. So, Mr. S. Pinkster did most of the interbreeding experiments, Mrs. A. L. Dennert executed the sodium determinations, Mrs. B. Stock plotted the distribution pattern and correlated the wateranalyses, Mr. J. H. Stock contributed the morphological and biometric analyses. The species identifications were done by Mr. S. Pinkster, Mr. J. H. Stock, Mr. W. M. van der Leeuw, and Mrs. C. C. M. van der Leeuw-Leegwater.

\section{REFERENCES}

Alten, H. von, 1915. Hydrobiologische Studien über die Wirkung von Abwässern auf die Organismen unserer Gewässer, III. (Vieweg \& Sohn, Braunschweig).

Beadle, L. C. \& J. B. Cragg, 1940. Osmotic regulation in freshwater animals. Nature (London), 146: 588.
Chevreux, E. \& L. Fage, 1925. Amphipodes. Faune de France, $9: 1-488$.

DAHL, E. 1959. Intertidal ecology in the terms of poikilohalinity. Archivio Oceanogr. Limnol., 11 (Suppl.): 225-237. 
Dennert, H. G., A. L. Dennert, P. Kant, S. Pinkster \& J. H. STock, 1969. Upstream and downstream migrations in relation to the reproductive cycle and to environmental factors in the amphipod, Gammarus zaddachi. Bijdr. Dierk., 39 : $11-43$.

ForSman, B., 1951. Studies on Gammarus duebeni Lillj., with notes on some rockpool organisms in Sweden. Zool. Bidr. Uppsala, 29 : 215-237.

GurJanova, E. F. 1951. [Gammarids of the seas of the U.S.S.R. and adjacent waters]. (In Russian). Keys Fauna U.S.S.R., 41 : 1-1031.

HARTOG, C. DEN, 1964. The amphipods of the deltaic region of the rivers, Rhine, Meuse and Scheldt..., III. The Gammaridae. Neth. J. Sea Res., 2 (3) : $407-457$.

Hartog, C. Den \& A. S. Tulp, 1960. Hydrobiologische waarnemingen in Friesland (slot). Lev. Natuur, 63 (6) : 133-140.

HuBEndick, B., 1950. The effectiveness of passive dispersal in Hydrobia jenkinsi. Zool. Bidr. Uppsala, 28 : $493-504$.

Hunter, W. \& T. Warwick, 1957. Records of Potamopyrgus jenkinsi (Smith) in Scottish fresh waters over fifty years (1906-56). Proc. roy. Soc. Edinburgh, (B) $66: 360-373$.

HyNES, H. B. N., 1954. The ecology of Gammarus duebeni Lilljeborg and its occurrence in fresh water in western Britain. J. anim. Ecol., 23 : 38-84.

-, 1955a. Distribution of some freshwater amphipods in Britain. Verh. int. Ver. theor. angew. Limnol., 12 : $620-628$.

-, 1955b. The reproductive cycle of some British freshwater Gammaridae. J. anim. Ecol., 24 : 352-387.

-, 1959. On the occurrence of Gammarus duebeni Lilljeborg in fresh water and of Asellus meridianus Racovitza in western France. Hydrobiologia, 13 : 152155.

KINNE, O., 1952. Zum Lebenszyklus von Gammarus duebeni Lillj ... Verh. Inst. Meeresforsch. Bremerhaven, $1: 187-203$.

-, 1953. Zur Biologie und Physiologie von Gammarus duebeni Lillj. Z. wiss. Zool., 157 : 427-491.

LAGERSPETZ, K., 1963. Humidity reactions of three aquatic arthropods, Gammarus duebeni, G. oceanicus, and Pontoporeia affinis in the air. J. exp. Biol., 40 : 105110.

LAtTIN, G. DE, 1967. Grundriss der Zoogeographie: 1602. (Gustav Fischer, Jena).

Legueux, Marie-L. Le Roux, 1927. Crustacés Amphipodes de Normandie (formes marines, d'eau saumâtre et d'eau douce), 1 re contribution. Bull. Soc. Linn. Normandie, (7) $9: 34-43$.

LiLjeborg, W., 1852. Norges Crustacéer. Ofvers. kongl. Vet.-Akad. Förhandl., 8 (1851): 19-25.

MAYR, E., E. G. LinsLeY \& R. L. Usinger, 1953. Methods and principles of systematic zoology: i-ix, 1328. (McGraw-Hill, New York, Toronto, London).
Mrloslawskaja, N., 1931. Nachtrag zur Amphipodenfauna des Schwarzen Meeres. Trav. Stat. biol. Karadagh, $4: 49-51$.

Ofstad, K. \& O. Solem, 1966. Funn av Gammarus duebeni Lilljeborg i ferskvann i Trøndelag. Fauna (Norsk zool. Foren. Tiddsskr.), 19 (3): 149-159.

Ostwald, G. W. W., 1905. Studies on the toxicity of seawater for fresh-water animals (Gammarus pulex De Geer). Univ. California Publ. Physiol., 2 (18): 163-191.

Øxland, J., 1959. Om tangloppen Gammarus duebeni som b'e funnet ved Borrevann i sommer. Fauna (Norsk zool. Foren. Tidsskr.), 12 (1): 1-14.

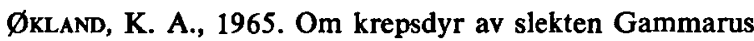
i freskvann of brakkvann i Norge. Fauna (Norsk zool. Foren. Tidsskr.), 18 (2) : 53-62.

Pacaud, A., 1952. Nouvelle revue de la distribution géographique des Gammares dans les eaux continentales françaises. C. R. Soc. biogéogr., 252-253 : 95-111.

REID, D. M., 1938. Forms of Gammarus from Ireland. Nature (London), 141 : 690.

- , 1939. On the occurrence of Gammarus duebeni (Lillj.) (Crustacea, Amphipoda) in Ireland. Proc. roy. Irish Acad., (B) $45: 207-214$.

Rijnberg, A. E., M. W. L. Sitsen, A. J. Kant-RietberGEN, J. H. STock \& P. KANT, 1967. Het voorkomen van Gammariden in een gedeelte van Bretagne met speciale opmerkingen over Gammarus duebeni Lilljeborg en Gammarus insensibilis Stock. Versl. zoöl. Werkexc. Roscoff 1966: 31-36, 1 map (Zoöl. Mus., Amsterdam, mimeographed).

Salvat, B., 1962. Faune des sédiments meubles intertidaux du Bassin d'Arcachon. Systématique et écologie. Cah. Biol. mar., 3 : 219-244.

Schмid, R., 1913. Die Salzwasserfauna Westfalens. Inaug. Diss.: 1-71. (Regenbergsche Buchdruckerei, Münster).

Schmitz, W., 1959. Zur Frage der Klassifikation der binnenländischen Brackwässer. Archivio Oceanogr. Limnol., 11 (Suppl.): 179-226).

Schmitz, W., W. BeSCh \& I. KNEISSL, 1967. Die Salzgehalttoleranz von Gammarus pulex pulex (L.), Gammarus tigrinus Sexton und Asellus aquaticus (L.) ... Int. Rev. ges. Hydrobiol., 52 (4): 589-616.

Segerstrale, S. G., 1946. On the occurrence of the amphipod, Gammarus duebeni (Lillj.) in Finland, with notes on the ecology of the species. Commentat. biol., 9 (18): $1-22$.

-, 1950. The amphipods on the coast of Finland some facts and problems. Commentat. biol., 10 (14) : $1-28$.

Steele, D. H. \& V. J. Steele, 1969. The biology of Gammarus in the northwestern Atlantic, I. Gammarus duebeni Lillj. Canad. J. Zool., 47 (2) : 235-244.

STock, J. H., 1967. A revison of the european species of the Gammarus locusta-group. Zool. Verhand., 90 : $1-56$. 
Stock, J. H., H. NiJssen \& P. Kant, 1966. La répartition écologique des Amphipodes de la famille des Gammaridae dans la Slack et son estuaire. Bull. zool. Mus. Univ. Amsterdam, 1 (3) : 19-30.

Stock, J. H. \& S. Pinkster, 1970. Irish and French freshwater populations of Gammarus duebeni subspecifically different from brackish water populations. Nature (London), in press.

SutclifFe, D. W., 1961. Salinity fluctuations and the fauna in a salt marsh, with special reference to aquatis insects. Trans. nat. Hist. Soc. Northumberl., (n.S.) 14 (2) : 39-56.

,- 1967 a. Sodium regulation in the amphipod Gammarus duebeni from brackish-water and fresh-water localities in Britain. J. exp. Biol., $46: 529-550$.

-, 1967b. The sodium balance mechanism in the freshwater amphipod, Gammarus lacustris Sars. J. exp. Biol., 46 : 519-528.
-, 1967c. A re-examination of observations on the distribution of Gammarus duebeni Lilljeborg in relation to the salt content in fresh water. J. anim. Ecol., 36 : 579-597.

-, 1970. Experimental populations of Gammarus duebeni in fresh water with a low sodium content. Nature (London), in press.

SUTCLIFFe, D. W. \& J. SHaw, 1968. Sodium regulation in the amphipod Gammarus duebeni Lilljeborg from freshwater localities in Ireland. J. exp. Biol., 48 : 339-358.

ToDD, M. E., 1964. Osmotic balance in Hydrobia ulvae and Potamopyrgus jenkinsi. J. exp. Biol., 41 : 665677.

VincenT, M., 1966. Vie en eau de mer diluée de quelques Gammaridés d'eau douce. Comparaison des glandes antennaires. C. R. Soc. Biol., 160 : 637-641.

WarWICK, T., 1952. Strains in the mollusc Potamopyrgus jenkinsi (Smith). Nature (London), 169 : 551-552. 